\title{
U.S. Households' Access to and Use of Electronic Banking, 1989-2007
}

Catherine J. Bell and Jeanne M. Hogarth, of the Board's Division of Consumer and Community Affairs, and Eric Robbins, of the Federal Reserve Bank of Kansas City, prepared this article.

Consumers are increasingly embracing electronic technology as a means of making payments and managing their personal finances. Data from the 2007 Federal Reserve Payments Study show a continuing shift away from paper-based transactions, such as payments by cash and check, and toward electronic transactions, in particular, automated deposits and payments and payments by debit card. ${ }^{1}$ The number of debit card payments, for example, increased from 15.6 billion to 25.3 billion between 2003 and 2006, and the dollar value of debit card payments increased as well (see box "How Would You Like to Pay for That?"). (Payments by credit card, as a proportion of all payments, remained constant over the period.)

Managing their financial matters electronically offers consumers many potential benefits: they can, for example, arrange for timely payments at virtually any time of the day or night and can avoid overdrafts by reviewing their account balances throughout the month. Yet concern remains that some technologies are not available to consumers at all income levels. ${ }^{2}$ There is also concern that data breaches in recent

1. Federal Reserve System (2007), "The 2007 Federal Reserve Payments Study: Noncash Payment Trends in the United States: 2003-2006," www.frbservices.org/files/communications/pdf/research/ 2007_payments_study.pdf. Also see Geoffrey R. Gerdes (2008), "Recent Payment Trends in the United States,"Federal Reserve Bulletin, vol. 94 (October), pp.75-106, www.federalreserve.gov/pubs/ bulletin/2008/pdf/payments08.pdf; Geoffrey R. Gerdes, Jack K. Walton II, May X. Liu, and Darrel W. Parke (2005), "Trends in the Use of Payment Instruments in the United States," Federal Reserve Bulletin, vol. 91 (Spring), pp. 180-201, www.federalreserve.gov/pubs/bulletin/ 2005/spring05_payment.pdf; and Visa USA Research Services (2006), "VISA Payment Panel Study: 2006 Payment Trends Study."

2. Eun-Ju Lee and Jinkook Lee (2000), "Haven't Adopted Electronic Financial Services Yet? The Acceptance and Diffusion of Electronic Banking Technologies," Financial Counseling and Planning, vol. 11 (1), pp. 49-60; Jeanne M. Hogarth, Jane M. Kolodinsky, and Tatiana Gabor (2006), "Consumer Payment Choices: Paper, Plastic_or Electrons?" Consumer Interests Annual (Proceedings of the 2006 annual conference of the American Council on Consumer Interests), vol. 52, pp. 127-40, www.consumerinterests.org/files/ public/Hogarth_ConsumerPaymentChoicesPaperPlasticorElectrons.pdf. years have reduced consumers' willingness to use some technologies. ${ }^{3}$

This article examines changes over time in consumers' access to, adoption of, and attitudes toward various forms of electronic banking (e-banking), including the use of automated teller machines (ATMs), debit cards, direct deposit, preauthorized payments, phone banking, online banking, smart cards, and prepaid cards. The article also updates data on electronic banking reported earlier and looks at several emerging technologies. ${ }^{4}$ The analyses are based on data from two sources: the Federal Reserve's triennial Survey of Consumer Finances (SCF) (surveys for 1989 through 2007) and questions included by the Federal Reserve in the University of Michigan Survey Research Center's Surveys of Consumers (surveys in 1999, 2003, and 2006). The two surveys are described in appendix A. Unless stated otherwise, all analyses were restricted to households that reported having an account with a bank, thrift institution, or credit union.

\section{ACCESSIBILITY OF BANKING SERVICES}

As the financial services industry has evolved, consumer access to financial services has increased, both in the number of brick-and-mortar bank branches and in the availability of e-banking services, such as ATMs and online banking. Despite a decline of almost 50 percent in the number of banks between

3. In a survey by the Princeton Research Group on behalf of Consumer Reports WebWatch, respondents reported having altered their use of credit cards because they were concerned about identity theft; see Consumer Reports WebWatch (2005), "Leap of Faith: Using the Internet Despite the Dangers" (October 26), www. consumerwebwatch.org/pdfs/princeton.pdf. Security concerns have also been cited as a barrier to consumer adoption of mobile banking; see Niina Mallat (2007), "Exploring Consumer Adoption of Mobile Payments: A Qualitative Study," Journal of Strategic Information Systems, vol. 16 (December), pp. 413-32.

4. Earlier data were reported in Christoslav E. Anguelov, Marianne A. Hilgert, and Jeanne M. Hogarth (2004), "U.S. Consumers and Electronic Banking, 1995-2003,'"Federal Reserve Bulletin, vol. 90 (Winter), pp. 1-18, www.federalreserve.gov/pubs/bulletin/2004/ winter04_ca.pdf. See that article for a comprehensive glossary of e-banking terms and a discussion of e-banking services. 


\section{How Would You Like to Pay for That?}

As new payment technologies have developed, consumers have changed the way they pay for the goods and services they buy. Although the number and volume of consumers' cash transactions cannot be measured accurately, indirect evidence suggests that cash transactions have declined. ${ }^{1}$ It is certain that the use of checks as a form of payment has declined substantially (table A). The decline between 2003 and 2006 was accompanied by an increase in the use of debit cards and the number of $\mathrm{ACH}$ payments (for example, preauthorized payments).

Several studies have looked at consumers' choices of form of payment under differing circumstances. One study found that French consumers make high-value

1. Geoffrey R. Gerdes (2008), "Recent Payment Trends in the United States," Federal Reserve Bulletin, vol. 94 (October), pp.75-106, www.federalreserve.gov/pubs/bulletin/2008/pdf/payments08.pdf; Paul W. Bauer and Daniel Littman (2007), "Are Consumers Cashing Out?" Federal Reserve Bank of Cleveland Economic Commentary (October), www.clevelandfed.org/research/commentary/2007/100107.cfm. payments by check, mid-value payments by cash or bank debit card, and low-value payments by cash. ${ }^{2}$ Another study found that the nature of the transaction, the transaction value, the environment at the point of sale, the bill's frequency, and the variability of the transaction value affect consumers' decisions about which form of payment to use. $^{3}$ Similarly, the 2006 Visa Payment Panel Study showed that in 2005 , U.S. consumers were more likely to use a credit card than another form of payment to pay for a meal at a high-priced restaurant, were likely to use cash or credit card to pay for a meal at a mid-priced restaurant,

2. David Bounie and Abel Francois (2006), "Cash, Check or Bank Card? The Effects of Transaction Characteristics on the Use of Payment Instruments," University of Paris Working Paper, www.bos.frb.org/ economic/eprg/conferences/payments2006/papers/Bounie.pdf.

3. Fumiko Hayashi and Elizabeth Klee (2003), "Technology Adoption and Consumer Payments: Evidence from Survey Data," Review of Network Economics, vol. 2 (June), pp. 175-90.

A. Distribution of payments, by payment method, 2003 and 2006

Percent

\begin{tabular}{|c|c|c|c|c|c|c|}
\hline \multirow{2}{*}{ Payment method } & \multicolumn{2}{|c|}{2003} & \multicolumn{2}{|c|}{2006} & \multicolumn{2}{|c|}{ Change, 2003 to 2006} \\
\hline & Dollar value & $\begin{array}{l}\text { Number of } \\
\text { transactions }\end{array}$ & Dollar value & $\begin{array}{l}\text { Number of } \\
\text { transactions }\end{array}$ & Dollar value & $\begin{array}{l}\text { Number of } \\
\text { transactions }\end{array}$ \\
\hline Checks . & 60.9 & 45.8 & 54.9 & 32.7 & -9.8 & -28.6 \\
\hline Cards ... & & & & & & \\
\hline Credit cards & 2.5 & 23.3 & 2.8 & 23.3 & 12.0 & .0 \\
\hline Debit cards. . & .9 & 19.2 & 1.3 & 27.1 & 44.4 & 41.1 \\
\hline $\mathrm{ACH} \ldots \ldots \ldots$ & 35.7 & 10.7 & 40.9 & 15.7 & 14.6 & 46.7 \\
\hline Electronic benefit transfers . & * & 1.0 & $*$ & 1.2 & $\ldots$ & 20.0 \\
\hline
\end{tabular}

NoTE: Components may not sum to 100 percent because of rounding.

* In absolute value, less than .05 percent.

... Not applicable.

Source: Gerdes, "Recent Payment Trends in the United States."

1980 and 2007 due to industry consolidation, the number of bank branches has climbed steadily, at a compound annual rate of growth of 2.7 percent. $^{5}$ Growth in the number of ATMs has been even more rapid, with a compound annual growth rate of 12.2 percent (figure 1). In particular, the growth of offpremises ATMs (ATMs not located within a bank branch) has allowed consumers greater access to their accounts.

5. One possible explanation for bank branch growth in an increasingly electronic world relates to the benefit of branch networks. Research by the Federal Deposit Insurance Corporation shows that banks with larger branch networks have greater deposit growth and higher returns on investment. See Gary Seale (2004), "Branching Continues to Thrive as the U.S. Banking System Consolidates," FYI: An Update on Emerging Issues in Banking (October 20), www.fdic.gov/ bank/analytical/fyi/2004/102004fyi.html.
1. Number of bank branches and ATMs in the United States, 1980-2007

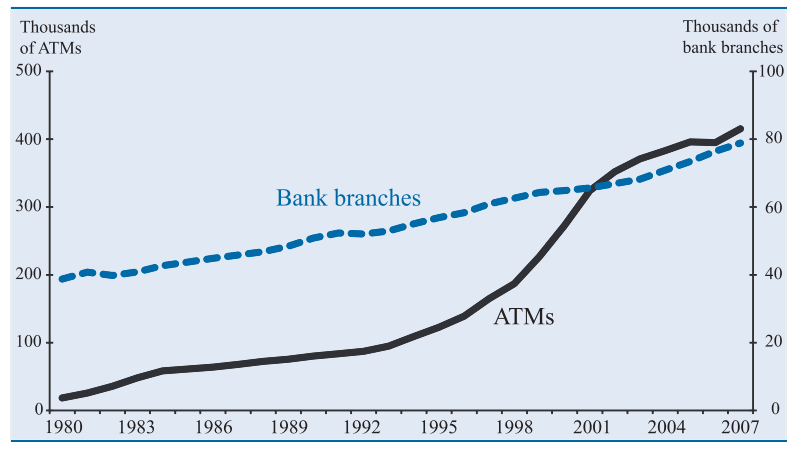

Source: Summary of Deposits and American Bankers Association. The Summary of Deposits (SOD) is an annual survey conducted by the Federal Deposit Insurance Corporation (FDIC) of branch office deposits as of June 30 for all FDIC-insured commercial banks, FDIC-supervised savings banks, and insured branches of all foreign banks. Current and historical SOD data can be accessed through the FDIC's website, at www2.fdic.gov/sod. 
and were likely to use cash at a quick-service restaurant (table B). ${ }^{4}$

Data from the 2006 Michigan Surveys of Consumers also reveal the tendencies of U.S. consumers to use different forms of payment for different types of transac-

4. Visa USA Research Services, "Visa Payment Panel Study." tions (table C). For Internet transactions, a small proportion of consumers use third-party payment systems (Pay$\mathrm{Pal}$, for example), perhaps reflecting concerns about fraud and data security. Although these transactions are settled within the banking system, many third-party services operate outside the regulated banking industry.

B. Distribution of consumer payments at various locations, by payment method, 2005

Percent

\begin{tabular}{|c|c|c|c|c|c|c|}
\hline \multirow[b]{2}{*}{ Payment location } & \multicolumn{6}{|c|}{ Payment method } \\
\hline & Cash & Check & $\begin{array}{c}\text { Credit card } \\
\text { (general purpose) }\end{array}$ & $\begin{array}{l}\text { Credit card } \\
\text { (private label } \\
\text { or proprietary) }\end{array}$ & Debit card & Other \\
\hline Gas stations & 20 & 4 & 35 & 8 & 30 & 1 \\
\hline Grocery stores. & 21 & 18 & 25 & 1 & 33 & 3 \\
\hline Department stores... & 9 & 13 & 33 & 26 & 17 & 3 \\
\hline Discount stores ........... & 16 & 17 & 26 & 3 & 37 & 2 \\
\hline Hotels. . & 9 & 2 & 73 & 5 & 10 & 1 \\
\hline High-priced restaurants. & 20 & 3 & 59 & 1 & 12 & 5 \\
\hline Mid-priced restaurants.... & 36 & 2 & 36 & 2 & 23 & 1 \\
\hline Quick-service restaurants . & 66 & 3 & 12 & 0 & 17 & 1 \\
\hline
\end{tabular}

NoTE: Components may not sum to 100 percent because of rounding.

Source: Visa USA Research Services, "VISA Payment Panel Study."

C. Method of payment, by transaction type, 2006

Percent

\begin{tabular}{|c|c|c|c|c|c|c|}
\hline \multirow{2}{*}{ Transaction type } & \multicolumn{6}{|c|}{ Payment method } \\
\hline & Cash & Check & Credit card & Debit card & Prepaid card & Third party ${ }^{1}$ \\
\hline In store (under \$25). & 43 & 8 & 18 & 31 & 0 & n.a. \\
\hline In store (over $\$ 25)$. & 16 & 16 & 35 & 33 & 0 & n.a. \\
\hline Internet............ & n.a. & 1 & 71 & 20 & 0 & 7 \\
\hline
\end{tabular}

Growth in the number of bank branches and ATMs narrows the distance between consumers and their financial services providers. In the 1989 Survey of Consumer Finances, 36 percent of respondents reported living or working within one mile of the nearest branch or ATM of their primary financial institution; by 2007, the proportion had grown to 41 percent (and 86 percent lived or worked within five miles) (table 1).

\section{Consumers' Banking Tendencies}

The ubiquity of bank branches means that most consumers have convenient access to traditional banking channels, such as brick-and-mortar branches and ATMs. And the use of direct deposit and preauthorized payments, together with the availability of financial services via telephone and computer, means that consumers can initiate most transactions 24 hours a day, from remote locations.

As the adoption of e-banking grows, one might expect brick-and-mortar branches to lose importance. However, surveys continue to show that the majority

1. Distance of home or workplace from closest branch or ATM, 1989 and 2007

Percent of respondents

\begin{tabular}{c|c|c|c|c}
\hline Year & $\begin{array}{c}\text { Less than } \\
1 \text { mile }\end{array}$ & $1-5$ miles & $6-10$ miles & $\begin{array}{c}\text { More than } \\
10 \text { miles }\end{array}$ \\
\hline $1989 \ldots \ldots \ldots \ldots . . .6 .2$ & 36.3 & 47.8 & 9.3 & 6.2 \\
$2007 \ldots \ldots \ldots \ldots$. & $40.8^{1}$ & 45.4 & 7.7 & 4.6 \\
\hline
\end{tabular}

NotE: Percentages do not sum to 100 percent because table does not include respondents who reported "mail" or "telephone" as the distance from the closest branch.

1. Includes 37.6 percent reporting "within 1 mile" and 3.2 percent reporting "the Internet"; the Internet was not mentioned in 1989.

Source: Survey of Consumer Finances. 
2. Main way of doing business with primary financial institution, by demographic characteristic, 2006

Percent

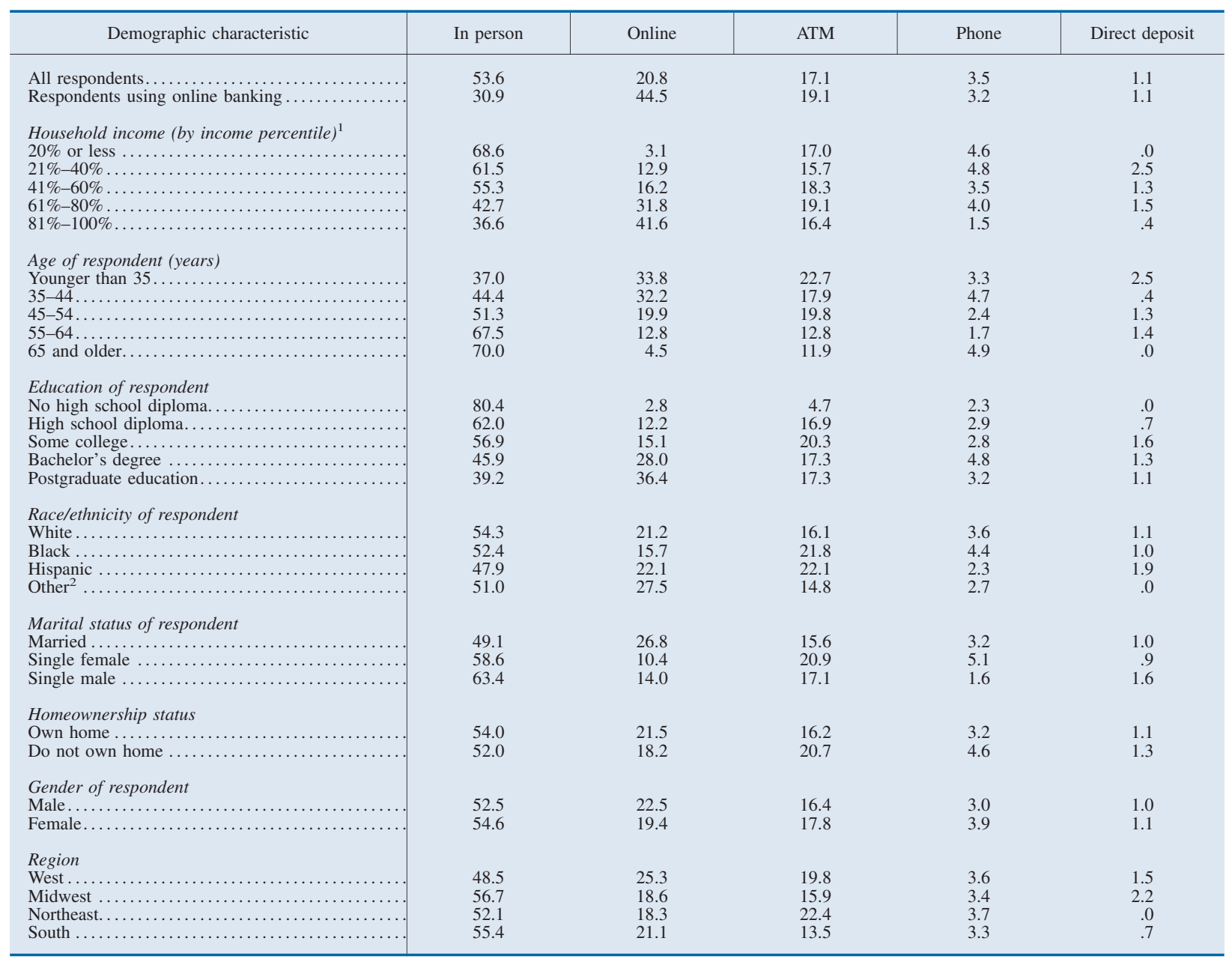

NotE: Percentages do not sum to 100 because of nonresponse.

2. Includes Asian, Pacific Islander, and Native American.

1. Income percentiles are based on the income of all responding households. Thus, of respondents in the lowest 20 percent of the income distribution, 68.6 percent reported doing business with their primary financial institution mainly in person and 3.1 percent reported doing business mainly online.

of consumers still conduct their bank business mainly in person (table 2). In the 2006 Michigan Surveys of Consumers, 54 percent of respondents said that in-person interaction was their main way of doing business with their primary financial institution. In contrast, 21 percent reported conducting bank business mainly online, and 17 percent reported conducting transactions mainly using ATMs. These results differ from those of the Survey of Consumer Finances, which asks about the "main ways of conducting business" with their financial institution, thus allowing for multiple responses. In the 2004 SCF, 77 percent of respondents said they did their banking in person, 64 percent reported using ATMs, and 50 percent reported using the mail. ${ }^{6}$
SOURCE: Michigan Surveys of Consumers.

Looking at just those respondents who bank online presents a far different picture. For example, a much smaller proportion of online bankers-only 31 percent-reported in-person interaction as their main way of doing business with their primary financial institution. A larger proportion-45 percentreported online banking as their main means of conducting business.

Differences in practices also exist among demographic groups. For example, consumers in the top

6. Loretta J. Mester (2006), "Changes in the Use of Electronic Means of Payment: 1995-2004," Federal Reserve Bank of Philadelphia Business Review (2nd quarter), pp. 26-30, www. philadelphiafed.org/research-and-data/publications/business-review/ 2006/q2/br_q2-2006-4_changes-electronic-means.pdf. 
3. Consumer access to Internet and use of Internet for online banking, by demographic characteristic, 2006 Percent

\begin{tabular}{|c|c|c|c|c|c|c|c|}
\hline \multirow{3}{*}{ Demographic characteristic } & \multicolumn{3}{|c|}{ Internet access at home } & \multirow{3}{*}{$\begin{array}{l}\text { Internet } \\
\text { access } \\
\text { at work: } \\
\text { Have access }\end{array}$} & \multirow{2}{*}{\multicolumn{3}{|c|}{$\begin{array}{l}\text { Distribution of online bankers by } \\
\text { location most frequently used to } \\
\text { access their financial institution }\end{array}$}} \\
\hline & \multirow{2}{*}{ Have access } & \multicolumn{2}{|c|}{$\begin{array}{l}\text { Distribution by type } \\
\text { of connection }\end{array}$} & & & & \\
\hline & & Dial-up & High-speed & & Home & Work & Both equally \\
\hline All respondents ................ & 72.3 & 27.1 & 72.9 & 52.2 & & & \\
\hline Respondents using online banking. & 95.1 & 18.7 & 81.3 & 75.5 & 78.2 & 14.4 & 7.4 \\
\hline 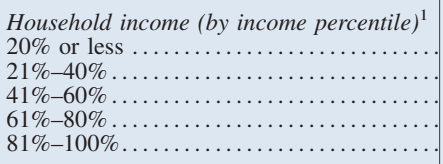 & $\begin{array}{l}36.6 \\
61.1 \\
76.7 \\
88.8 \\
96.3\end{array}$ & $\begin{array}{l}41.0 \\
44.8 \\
32.5 \\
22.9 \\
10.7\end{array}$ & $\begin{array}{l}59.0 \\
55.2 \\
67.5 \\
77.1 \\
89.3\end{array}$ & $\begin{array}{l}17.2 \\
41.0 \\
54.2 \\
73.5 \\
77.4\end{array}$ & $\begin{array}{l}89.1 \\
72.3 \\
80.2 \\
81.4 \\
74.6\end{array}$ & $\begin{array}{l}10.9 \\
16.9 \\
15.7 \\
14.3 \\
14.2\end{array}$ & $\begin{array}{r}.0 \\
10.7 \\
4.2 \\
4.4 \\
11.2\end{array}$ \\
\hline 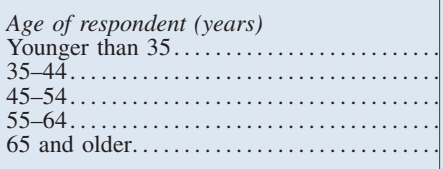 & $\begin{array}{l}79.2 \\
86.9 \\
79.1 \\
73.1 \\
45.9\end{array}$ & $\begin{array}{l}25.5 \\
20.1 \\
22.5 \\
33.8 \\
42.5\end{array}$ & $\begin{array}{l}74.5 \\
79.9 \\
77.5 \\
66.2 \\
57.5\end{array}$ & $\begin{array}{r}67.8 \\
73.2 \\
66.5 \\
46.3 \\
9.8\end{array}$ & $\begin{array}{l}73.3 \\
80.0 \\
75.0 \\
81.6 \\
95.0\end{array}$ & $\begin{array}{r}21.1 \\
12.6 \\
14.4 \\
8.6 \\
5.0\end{array}$ & $\begin{array}{r}5.6 \\
7.4 \\
10.6 \\
9.9 \\
.0\end{array}$ \\
\hline 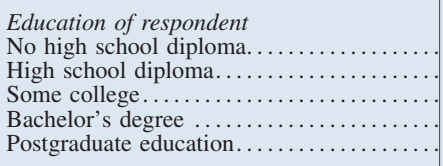 & $\begin{array}{l}21.8 \\
60.7 \\
71.0 \\
84.6 \\
89.7\end{array}$ & $\begin{array}{l}57.5 \\
40.9 \\
30.2 \\
21.2 \\
16.2\end{array}$ & $\begin{array}{l}42.6 \\
59.2 \\
69.8 \\
78.8 \\
83.8\end{array}$ & $\begin{array}{l}11.6 \\
32.4 \\
51.2 \\
66.8 \\
74.1\end{array}$ & $\begin{array}{l}50.0 \\
83.5 \\
76.4 \\
78.3 \\
77.3\end{array}$ & $\begin{array}{r}.0 \\
10.5 \\
13.6 \\
13.1 \\
20.8\end{array}$ & $\begin{array}{r}50.0 \\
6.0 \\
10.1 \\
8.6 \\
2.0\end{array}$ \\
\hline 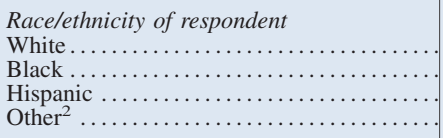 & $\begin{array}{l}75.1 \\
55.7 \\
59.6 \\
79.4\end{array}$ & $\begin{array}{l}27.3 \\
28.7 \\
18.9 \\
22.7\end{array}$ & $\begin{array}{l}72.7 \\
71.3 \\
81.1 \\
77.3\end{array}$ & $\begin{array}{l}52.5 \\
56.0 \\
46.8 \\
52.3\end{array}$ & $\begin{array}{l}78.3 \\
70.1 \\
89.7 \\
73.9\end{array}$ & $\begin{array}{r}13.9 \\
27.8 \\
.0 \\
23.1\end{array}$ & $\begin{array}{r}7.8 \\
2.1 \\
10.3 \\
3.1\end{array}$ \\
\hline $\begin{array}{l}\text { Marital status of respondent } \\
\text { Married .................... } \\
\text { Single female } \ldots \ldots \ldots \ldots \ldots \\
\text { Single male } \ldots \ldots \ldots \ldots \ldots\end{array}$ & $\begin{array}{l}81.6 \\
54.9 \\
63.9\end{array}$ & $\begin{array}{l}27.0 \\
27.6 \\
27.0\end{array}$ & $\begin{array}{l}73.0 \\
72.4 \\
73.0\end{array}$ & $\begin{array}{l}57.8 \\
39.2 \\
51.1\end{array}$ & $\begin{array}{l}78.6 \\
82.9 \\
73.5\end{array}$ & $\begin{array}{l}13.0 \\
12.5 \\
20.9\end{array}$ & $\begin{array}{l}8.4 \\
4.6 \\
5.6\end{array}$ \\
\hline $\begin{array}{l}\text { Homeownership status } \\
\text { Own home } \ldots \ldots \ldots \ldots \ldots \ldots \\
\text { Do not own home } \ldots \ldots \ldots \ldots\end{array}$ & $\begin{array}{l}76.5 \\
55.4\end{array}$ & $\begin{array}{l}28.6 \\
19.0\end{array}$ & $\begin{array}{l}71.4 \\
81.0\end{array}$ & $\begin{array}{l}53.2 \\
47.9\end{array}$ & $\begin{array}{l}80.0 \\
70.2\end{array}$ & $\begin{array}{l}14.0 \\
16.1\end{array}$ & $\begin{array}{r}6.1 \\
13.7\end{array}$ \\
\hline $\begin{array}{l}\text { Gender of respondent } \\
\text { Male } \ldots \ldots \ldots \ldots \ldots \ldots \ldots \\
\text { Female.............. }\end{array}$ & $\begin{array}{l}76.0 \\
69.2\end{array}$ & $\begin{array}{l}25.2 \\
28.9\end{array}$ & $\begin{array}{l}74.8 \\
71.1\end{array}$ & $\begin{array}{l}58.8 \\
46.5\end{array}$ & $\begin{array}{l}79.2 \\
77.3\end{array}$ & $\begin{array}{l}11.3 \\
17.3\end{array}$ & $\begin{array}{l}9.6 \\
5.4\end{array}$ \\
\hline $\begin{array}{l}\text { Region } \\
\text { West ......... } \\
\text { Midwest .... } \\
\text { Northeast. .... } \\
\text { South ....... }\end{array}$ & $\begin{array}{l}78.0 \\
70.6 \\
73.4 \\
69.6\end{array}$ & $\begin{array}{l}23.2 \\
32.6 \\
22.2 \\
28.8\end{array}$ & $\begin{array}{l}76.8 \\
67.4 \\
77.8 \\
71.2\end{array}$ & $\begin{array}{l}53.0 \\
47.1 \\
54.9 \\
53.7\end{array}$ & $\begin{array}{l}83.0 \\
75.7 \\
75.4 \\
78.2\end{array}$ & $\begin{array}{l}11.7 \\
18.6 \\
17.7 \\
11.3\end{array}$ & $\begin{array}{r}5.3 \\
5.8 \\
6.9 \\
10.4\end{array}$ \\
\hline
\end{tabular}

NotE: Some percentages do not sum to 100 because of rounding or nonresponse.

1. Income percentiles are based on the income of all responding households. Thus, of respondents in the lowest 20 percent of the income distribution, 36.6 percent reported having Internet access at home and, of that group, 41.0 percent reported having a dial-up connection.

fifth in terms of income tended to report using online banking as their main way of doing business with their primary financial institution (42 percent), whereas consumers with less income reported in-person banking as their main way of conducting bank business (perhaps in part because of a lack of access to the Internet). Compared with those over the age of 45 , larger proportions of respondents under 45 reported using online banking or ATMs as their main way of doing business with their primary financial institution. Education level appears to be associated with online banking as well: larger proportions of respon-
2. Includes Asian, Pacific Islander, and Native American. . Not applicable. SOURCE: Michigan Surveys of Consumers.

dents with a bachelor's degree or postgraduate education reported online banking as their main way of banking.

\section{Extent of Consumer Access to the Internet}

Nearly three-fourths of respondents to the 2006 Michigan Surveys of Consumers reported having Internet access at home (72 percent), and about half reported having access at work (52 percent). Most consumers with home access had a high-speed connection (73 percent) (table 3 ). For online bankers, the 
majority (78 percent) reported that they do their online banking most often from home.

Several demographic factors-including age, education, race and ethnicity, and income-seem to be associated with Internet access. The same groups less likely to cite online banking as their primary means of conducting bank business were also less likely to have Internet access at home. For example, respondents older than 65 were less likely to have Internet access at home and less likely to have a high-speed Internet connection. Similarly, only 22 percent of respondents without a high school diploma reported having Internet access at home, and only 12 percent reported having access at work. In addition, black and Hispanic respondents were less likely than white and "other" (predominantly Asian, Pacific Islander, and Native American) respondents to have Internet access at home-although those who had home access were just as likely as white and "other" respondents to have a high-speed connection. In a multivariate modeling of Internet access, black respondents were the only group statistically less likely to have access, either at work or at home (data not shown).

Between 2000 and 2006, access to computers and the Internet became more widespread across all income groups. ${ }^{7}$ However, data from the 2006 Michigan Surveys of Consumers indicate that differences among households in different income groups remain. About 50 percent of low- and moderate-income households (those in the first and second income quintiles, the lower 40 percent of the income distribution) had Internet access at home, compared with nearly 90 percent of middle- and higher-income households (those in the upper 60 percent of the income distribution); similarly, about 30 percent in the lower income group reported having Internet access at work, compared with nearly 70 percent in the upper income group. ${ }^{8}$

Even for those with Internet access at home, the type of access varies by income, with higher proportions of lower income households accessing their home Internet service provider via a slower dial-up

7. U.S. Census (2001), "Home Computers and Internet Use in the United States: August 2000" (September), www.census.gov/prod/ 2001pubs/p23-207.pdf; U.S. Census (2005), "Computer and Internet Use in the United States: 2003" (October), www.census.gov/prod/ 2005pubs/p23-208.pdf; 2008 Statistical Abstract of the United States, "Internet Access and Usage and Online Service Usage: 2006" (table 1127), www.census.gov/compendia/statab/2008/tables/ 08s1127.pdf.

8. Here and elsewhere in this article, "low income" refers to households in the first income quintile (lowest 20 percent of the income distribution), "moderate income" refers to those in the second quintile, "middle income" refers to those in the third quintile, and "higher income" generally refers to those in the upper two quintiles. connection rather than a high-speed connection. This finding has implications for the use of online banking, as consumers may find online banking via a dial-up connection cumbersome and may believe that highspeed connections are more secure. As discussed later, consumers' perceptions of the convenience and security of e-banking products affect their willingness to adopt these products.

\section{TRENDS IN CONSUMER ADOPTION OF E-BANKING}

Consumer adoption of some mature e-banking technologies seems to have reached saturation. For example, the proportion of households reporting that they use direct deposit for income or benefits payments was at 80 percent in 2007 (table 4). ATM use remained fairly stable, at 67 percent and 69 percent in 2003 and 2006, respectively (though a higher proportion reported using ATM cards in 2007).

Adoption of other, newer e-banking technologies has been growing. In particular, the use of debit cards has increased in recent years-although some consider debit cards a "mature" technology, given their widespread use. 9 (Debit cards have been around long enough and have been used in a sufficient number of transactions that a few problems are being recognized, among them account overdrafts; see box "Account Debits and Overdrafts.") Only 20 percent of respondents to the 1995 Survey of Consumer Finances had used a debit card; by 2007, the percentage had more than tripled, to 71 percent. The increase may have been due to several factors. In the mid1990s, banks began to issue debit cards imprinted with the Visa or MasterCard logo, leading to acceptance by more merchants. ${ }^{10}$ Also, the addition of national credit card networks enabled consumers to complete transactions with only a signature anywhere a merchant accepted the card-in contrast to the requirement, when debit cards were introduced, that they use a personal identification number (PIN). Wider merchant acceptance and the elimination in many instances of the PIN requirement resulted in a significant increase in debit transactions in general,

9. Julia S. Cheney (2007), "An Update on Trends in the Debit Card Market," Payment Cards Center Discussion Paper 07-07 (Philadelphia: Federal Reserve Bank of Philadelphia, June), www. philadelphiafed.org/payment-cards-center/publications/discussionpapers/2007/D2007JuneUpdateDebitCardMarketTrends.pdf.

10. Stan Sienkiewicz (2002), "The Evolution of EFT Networks from ATMs to New On-Line Debit Payment Products," Payment Cards Center Discussion Paper 02-04 (Philadelphia: Federal Reserve Bank of Philadelphia, April), www.philadelphiafed.org/pcc/papers/ 2002/EFTNetworks_042002.pdf. 
4. Proportion of U.S. households that use various electronic banking technologies, selected years Percent

\begin{tabular}{|c|c|c|c|c|c|c|c|c|c|c|}
\hline \multirow[b]{2}{*}{ Technology } & \multicolumn{6}{|c|}{ Survey of Consumer Finances } & \multicolumn{4}{|c|}{ Michigan Surveys of Consumers } \\
\hline & 1995 & 1998 & 2001 & 2004 & 2007 & $\begin{array}{c}\text { Change, } \\
1995 \text { to } \\
2007\end{array}$ & 1999 & 2003 & 2006 & $\begin{array}{c}\text { Change, } \\
1999 \text { to } \\
2006\end{array}$ \\
\hline Direct deposit & 53 & 67 & 73 & 76 & 80 & 50 & 65 & 70 & 77 & 19 \\
\hline ATM card .... & 35 & 55 & 58 & 66 & 76 & 116 & 59 & 67 & 69 & 16 \\
\hline Debit card.................. & 20 & 37 & 50 & 63 & 71 & 254 & n.a. & 54 & 62 & \\
\hline Preauthorized payment. & 25 & 40 & 44 & 51 & 49 & 95 & 31 & 46 & 57 & 84 \\
\hline Automated phone system & n.a. & 26 & 23 & 21 & 25 & & 40 & 44 & 46 & 16 \\
\hline Online banking ............ & 4 & 7 & 21 & 35 & 53 & 1,228 & 10 & 32 & 51 & 411 \\
\hline Smart card ..... & 1 & 2 & 3 & n.a. & n.a. & $\ldots$ & n.a. & 6 & 12 & $\ldots$ \\
\hline Prepaid card. & n.a. & n.a. & n.a. & n.a. & n.a. & $\cdots$ & n.a. & 73 & 73 & $\ldots$ \\
\hline
\end{tabular}

NotE: The numbers in this table differ from those in Mester, "Changes in the Use of Electronic Means of Payment: 1995-2004," in that Mester's data include all households whereas the data in this table include only those households that have bank accounts, consistent with Anguelov, Hilgert, and Hogarth, "U.S. Consumers and Electronic Banking." In addition, for those households with ATM cards, this table includes only those households that use the product, whereas Mester (see note b to her table "Percent of U.S. Households that Use

and in signature debit transactions (as opposed to PIN debit transactions) in particular.

The data indicate that consumers may be using some technologies as substitutes (using one or the other) and other technologies as complements (using both). For example, there is some evidence that consumers are using debit cards as substitutes for checks and cash and that those who are not using debit cards for transactions are using credit cards. ${ }^{11}$ (The decision about which form of payment to use may be driven in part by the size and circumstances of the transaction; see box "How Would You Like to Pay for That?") Similarly, consumers may use either online or phone banking, rather than both. Or they may use preauthorized payments and phone or online banking as complementary means of paying bills.

In 2006, more than half of consumers reported using preauthorized payments, up from about onefourth in the mid-1990s. Preauthorized payments

11. Ron Borzekowski, Elizabeth K. Kiser, and Shaista Ahmed (2006), "Consumers' Use of Debit Cards: Patterns, Preferences, and Price Response," Finance and Economics Discussion Series 2006-16 (Washington: Board of Governors of the Federal Reserve System, April), www.federalreserve.gov/pubs/feds/2006/200616/200616pap. pdf; Elizabeth Klee (2006), "Families' Use of Payment Instruments during a Decade of Change in the U.S. Payment System," Finance and Economics Discussion Series 2006-01 (Washington: Board of Governors of the Federal Reserve System, February), www. federalreserve.gov/pubs/feds/2006/200601/200601pap.pdf; Fumiko Hayashi and Elizabeth Klee (2003), "Technology Adoption and Consumer Payments: Evidence from Survey Data," Review of Network Economics, vol. 2 (June), pp 175-90; Elizabeth Klee, "How People Pay: Evidence from Grocery Store Data" (2008), Journal of Monetary Economics, vol. 55 (April), pp. 526-41; Marques Benton, Krista Blair, Marianne Crowe, and Scott Schuh (2007), "The Boston Fed Study of Consumer Behavior and Payment Choice: A Survey of Federal Reserve System Employees," Public Policy Discussion Papers No. 07-1 (Boston: Federal Reserve Bank of Boston, February), www.bos.frb.org/economic/ppdp/2007/ppdp0701.pdf.
Each Instrument: 1995, 1998, 2001, and 2004") indicates that she included any household that reported owning an ATM card.

Calculations may not yield change shown because of rounding.

n.a. Not available.

. . Not applicable.

SourcE: Survey of Consumer Finances and Michigan Surveys of Consumers.

allow consumers to have many types of bills paid automatically from their bank account-rent or mortgage, car payments, utility bills, or gym memberships, for example. Paying in this way helps consumers avoid late fees and maintain a sound credit record. While preauthorized payments can reduce consumers' costs in terms of their time and effort, they can also increase their "switching" costs, for example, the time it takes to change to a new financial institution, or the expense of stopping payment should the consumer wish to terminate his or her relationship with a current recipient of a preauthorized payment.

Online banking has clearly been the fastest growing e-banking technology over the past decade: fewer than 5 percent of consumers were banking online in 1995, compared with 53 percent in 2007. While most online bankers use the service to monitor their accounts or transfer funds, a significant proportion in 2006 were using online banking to pay bills (table 5). In 2003, only 32 percent of households reported banking online, and 55 percent of those online bankers were paying bills online; by 2006, of the 51 per-

5. Proportion of online bankers using various online banking services, 2003 and 2006

Percent

\begin{tabular}{|c|c|c|}
\hline Service & 2003 & 2006 \\
\hline Monitor accounts . & 95.4 & 97.7 \\
\hline Transfer funds between accounts & 63.9 & 70.1 \\
\hline Pay bills .................... & 54.7 & 76.0 \\
\hline Open new accounts & n.a. & 14.8 \\
\hline Apply for loans..... & n.a. & 11.1 \\
\hline МЕмо & & \\
\hline Proportion of respondents banking online & 32 & 51 \\
\hline
\end{tabular}

n.a. Not available.

SOURCE: Michigan Surveys of Consumers. 


\section{Account Debits and Overdrafts}

A 2007 study by PULSE EFT Association and Dove Consulting found that an increasing proportion of debit card programs authorize purchases "even when there are insufficient funds in the underlying demand deposit account at the time of the transaction, in essence allowing cardholders to overdraw their accounts." ${ }^{11}$ In these cases, consumers may face an overdraft fee from their bank. Financial institutions contend that consumers may be willing to pay overdraft fees rather than have their transactions denied, while consumer advocates contend that consumers should be given the choice of canceling or continuing their transactions.

In December 2008, the Federal Reserve Board issued final rules that amend the Board's Regulation DD (Truth in Savings) to address depository institutions' disclosure practices related to overdrafts. The new rules take effect January 1, 2010.

- Disclosure of aggregate overdraft fees. All institutions must disclose on their periodic statements the aggregate dollar amounts charged for overdrafts and returned items, both for the statement period and for the year to date. (Previously, only institutions that promote or advertise the payment of overdrafts were required to disclose aggregate amounts.)

- Disclosure of balance information. Institutions that provide account balance information through an automated system must provide a balance that does not include additional funds that may be made available to cover overdrafts.

At the same time the Board issued these final rules, it also issued proposed rules for overdraft services. The proposed rules, which would amend the Board's Regula-

1. The PULSE EFT Association and Dove Consulting study is described in Julia S. Cheney (2007), "An Update on Trends in the Debit Card Market," Payment Cards Center Discussion Paper 07-07 (Philadelphia: Federal Reserve Bank of Philadelphia, June), www. philadelphiafed.org/payment-cards-center/publications/discussion-papers/ 2007/D2007JuneUpdateDebitCardMarketTrends.pdf. tion E (Electronic Fund Transfers), provide certain consumer protections related to the assessment of overdraft fees.

- Consumer choice regarding overdraft services. The proposal solicits comment on two approaches to giving consumers a choice regarding the payment of ATM and one-time debit card overdrafts by their financial institution.

- Opt-out. Under one approach, an institution would be prohibited from imposing an overdraft fee unless (1) the consumer is given an initial notice and a reasonable opportunity to opt out of the institution's overdraft service and (2) the consumer does not opt out.

- Opt-in. Under the other approach, an institution would be prohibited from imposing an overdraft fee unless the consumer affirmatively consents ("opts in") to the institution's overdraft service.

- Debit holds. The proposed rules would prohibit institutions from imposing an overdraft fee when the account is overdrawn because of a hold on funds in the consumer's account that exceeds the actual transaction amount. For example, when a consumer uses a debit card to pay for gasoline, the initial authorization may place a hold for $\$ 50$; the consumer may want to purchase only $\$ 20$ worth of gas, but if he or she has only $\$ 40$ in the account, the $\$ 50$ hold may overdraw the account. The proposed rule is limited to debit card transactions in which the actual transaction amount generally can be determined within a short time after the transaction is authorized (for example, transactions at gas stations and restaurants).

For details and to track the progress of these proposals, visit www.federalreserve.gov/newsevents/press/bcreg/ 20081218a.htm. The comment period for these proposals closed on March 30, 2009. cent of households banking online, 76 percent were paying bills online.

Compared with online bill paying, other online banking services, such as opening new accounts, are used much less frequently (appendix table B.1). In 2006, only about 15 percent of online bankers used online banking to open a new account, and only 11 percent used online banking to apply for a loan. Because not all banks offer a full range of services online, some of these numbers may reflect the supply of, as well as the demand for, e-banking services.
Nearly three out of four respondents to the 2003 and 2006 Michigan Surveys of Consumers reported using some type of prepaid, or stored-value, card. Some of these cards may be closed-system, or singlevendor, cards (for example, gift cards from a particular store); others may be general-purpose cards that carry a Visa, MasterCard, or American Express logo. Some cards are designed for a single use, while others are reloadable; for example, some employers issue reloadable payroll cards to employees who do not have their pay deposited directly into a bank 
account. ${ }^{12}$ Between 2004 and 2007, the number of transactions made via prepaid cards grew from 2.4 billion to 4.3 billion; the dollar volume grew in approximately the same proportion, from $\$ 64$ billion to $\$ 113$ billion. While the majority of these prepaid card transactions were made by closed-system cards, the share made by general-purpose cards grew from 20 percent to 28 percent over the period. ${ }^{13}$ Consumer and community educators have advocated the use of these cards as a way to transition unbanked and underbanked households to the mainstream banking system. However, many of these cards are not associated with a bank account.

\section{Users of E-Banking}

In addition to the benefits of using e-banking products and services noted earlier, studies suggest that consumers who monitor their bank accounts electronically identify fraudulent transactions earlier than consumers who rely on paper statements. ${ }^{14}$ If this is the case, then it is important to identify barriers to the adoption of e-banking technologies so that consumers can be encouraged to use these products for their own benefit.

Consumers' access to bank accounts and their use of e-banking products is correlated with demographic factors such as age, income, race and ethnicity, and education. ${ }^{15}$ Given that the number of e-banking

12. James C. McGrath (2007), "General-Use Prepaid Cards: The Path to Gaining Mainstream Acceptance," Payment Cards Center Discussion Paper 07-03 (Philadelphia: Federal Reserve Bank of Philadelphia, March), www.philadelphiafed.org/pcc/papers/2007/ D2007MarchGeneralUsePrepaidCards.pdf; Julia S. Cheney and Sherrie L.W. Rhine (2006), "Prepaid Cards: An Important Innovation in Financial Services," Payment Cards Center Discussion Paper 06-07 (Philadelphia: Federal Reserve Bank of Philadelphia, July), www.philadelphiafed.org/pcc/papers/2006/ D2006JulyPrepaidCardsACCIcover.pdf; Julia S. Cheney (2007), "Payments, Credit, and Savings: The Experience for LMI Households," Summary of Payment Cards Center conference (Philadelphia: Federal Reserve Bank of Philadelphia), www.philadelphiafed.org/pcc/ conferences/2007/C2007MayExperienceforLMI.pdf.

13. Aite Group (2007), "Prepaid Cards: The State of the Industry," Report 200707231 (July), www.aitegroup.com/reports/ 200707231.php; and ATM \& Debit News and Prepaid Trends, New York: Source Media, September 27, 2007. Gerdes ("Recent Payment Trends in the United States") estimates that approximately 3.3 billion prepaid card payments, with a dollar volume of approximately $\$ 49.6$ billion, were made in 2006.

14. Mary T. Monahan (2007), "Identify Fraud Is Dropping, Continued Vigilance Necessary," Javelin Strategy and Research 2007 Identity Fraud Survey Report (February).

15. Lee and Lee, "Haven't Adopted Electronic Financial Services Yet?"; Eun Ju Lee, Jinkook Lee, and David Eastwood (2003), “A Two-Step Estimation of Consumer Adoption of Technology-Based Service Innovations," Journal of Consumer Affairs, vol. 37 (December), pp. 256-82; Jane M. Kolodinsky, Jeanne M. Hogarth, and Marianne A. Hilgert (2004), "The Adoption of Electronic Banking Technologies by U.S. Consumers," International Journal of Bank products used by consumers has increased, it may be instructive to look at how various demographic groups-some of which may be underrepresented among electronic bankers-have fared.

\section{Income and E-Banking}

Data from the Michigan Surveys of Consumers confirm that higher income households are more likely than those in other income groups to have a bank account and to use each of the electronic banking services covered in the surveys (table 6). However, low- and moderate-income households appear to be catching up: by 2006, 80 percent of low-income households and 94 percent of moderate-income households reported having a bank account. And while each income group has shown growth in the adoption of e-banking technologies, the growth has been especially noticeable among low- and moderate-income consumers. For example, the proportion of low- and moderate-income households using preauthorized payments more than doubled between 1999 and 2006. And low-income consumers reported an even larger increase in online banking, with the proportion rising tenfold, from 3 percent to 30 percent, between 1999 and 2006. Despite significant growth in the percentage of low-income consumers banking online, the difference between the lowest and highest income groups in the percentages banking online appears to have widened over time, from 19 percentage points in 1999 to 26 percentage points in 2003 to 40 percentage points in 2006. Finally, the proportion of low-income consumers banking by phone more than doubled from 1999 to 2006, perhaps an indication that phone banking is a substitute for online banking among lower-income households.

Does their increased use of online banking, phone banking, and preauthorized payments mean that lowand moderate-income consumers are better off? While this question cannot be answered definitively, it is possible that these consumers are better able to monitor their account activity and balances with these e-banking technologies. Interestingly, when attitudes and other demographic characteristics were controlled for in the 2006 data, income was not a significant determinant of whether a household banked online, banked by phone, or used preauthorized payment (data not shown).

Marketing, vol. 22 (4), pp. 238-59; Borzekowski, Kiser, and Ahmed. "Consumers' Use of Debit Cards"; Michal Polasik and Tomasz Piotr Wisniewski (2008), "Empirical Analysis of Internet Banking Adoption in Poland" (June 22), paper presented at the 21st Australasian Finance and Banking Conference, papers.ssrn.com/sol3/ papers.cfm?abstract_id=1116760. 
6. Use of e-banking products and services by consumers who have a bank account, by demographic characteristic, selected years

Percent

\begin{tabular}{|c|c|c|c|c|c|c|c|c|c|c|c|c|}
\hline \multirow{3}{*}{ Demographic characteristic } & \multirow{2}{*}{\multicolumn{3}{|c|}{ Have a bank account }} & \multicolumn{9}{|c|}{ Product or service } \\
\hline & & & & \multicolumn{3}{|c|}{ ATM card } & \multicolumn{3}{|c|}{ Debit card } & \multicolumn{3}{|c|}{ Direct deposit } \\
\hline & 1999 & 2003 & 2006 & 1999 & 2003 & 2006 & 1999 & 2003 & 2006 & 1999 & 2003 & 2006 \\
\hline All respondents... & 89 & 86 & 92 & 60 & 67 & 69 & n.a. & 54 & 62 & 66 & 70 & 77 \\
\hline 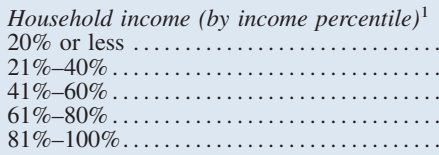 & $\begin{array}{l}67 \\
89 \\
93 \\
98 \\
97\end{array}$ & $\begin{array}{l}67 \\
82 \\
92 \\
92 \\
98\end{array}$ & $\begin{array}{l}80 \\
94 \\
97 \\
98 \\
97\end{array}$ & $\begin{array}{l}34 \\
47 \\
60 \\
68 \\
82\end{array}$ & $\begin{array}{l}57 \\
71 \\
72 \\
68 \\
72\end{array}$ & $\begin{array}{l}58 \\
66 \\
63 \\
79 \\
83\end{array}$ & $\begin{array}{l}\text { n.a. } \\
\text { n.a. } \\
\text { n.a. } \\
\text { n.a. } \\
\text { n.a. }\end{array}$ & $\begin{array}{l}49 \\
58 \\
60 \\
53 \\
55\end{array}$ & $\begin{array}{l}50 \\
65 \\
61 \\
71 \\
69\end{array}$ & $\begin{array}{l}63 \\
70 \\
60 \\
65 \\
72\end{array}$ & $\begin{array}{l}59 \\
69 \\
68 \\
80 \\
73\end{array}$ & $\begin{array}{l}71 \\
74 \\
79 \\
84 \\
81\end{array}$ \\
\hline 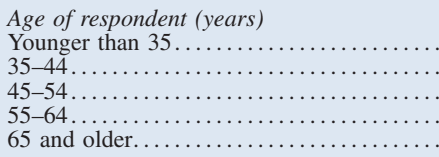 & $\begin{array}{l}87 \\
87 \\
91 \\
87 \\
91\end{array}$ & $\begin{array}{l}81 \\
88 \\
90 \\
91 \\
83\end{array}$ & $\begin{array}{l}88 \\
95 \\
95 \\
91 \\
92\end{array}$ & $\begin{array}{l}79 \\
74 \\
58 \\
52 \\
19\end{array}$ & $\begin{array}{l}84 \\
77 \\
62 \\
58 \\
45\end{array}$ & $\begin{array}{l}89 \\
80 \\
76 \\
57 \\
41\end{array}$ & $\begin{array}{l}\text { n.a. } \\
\text { n.a. } \\
\text { n.a. } \\
\text { n.a. } \\
\text { n.a. }\end{array}$ & $\begin{array}{l}79 \\
64 \\
43 \\
39 \\
30\end{array}$ & $\begin{array}{l}86 \\
76 \\
64 \\
52 \\
32\end{array}$ & $\begin{array}{l}58 \\
67 \\
60 \\
57 \\
89\end{array}$ & $\begin{array}{l}60 \\
70 \\
66 \\
76 \\
83\end{array}$ & $\begin{array}{l}71 \\
78 \\
73 \\
75 \\
89\end{array}$ \\
\hline 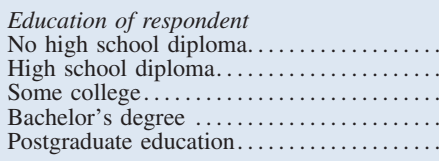 & $\begin{array}{l}67 \\
88 \\
93 \\
92 \\
97\end{array}$ & $\begin{array}{l}44 \\
81 \\
88 \\
95 \\
97\end{array}$ & $\begin{array}{l}70 \\
88 \\
97 \\
95 \\
99\end{array}$ & $\begin{array}{l}23 \\
45 \\
70 \\
67 \\
85\end{array}$ & $\begin{array}{l}55 \\
60 \\
70 \\
72 \\
71\end{array}$ & $\begin{array}{l}49 \\
57 \\
73 \\
77 \\
75\end{array}$ & $\begin{array}{l}\text { n.a. } \\
\text { n.a. } \\
\text { n.a. } \\
\text { n.a. } \\
\text { n.a. }\end{array}$ & $\begin{array}{l}42 \\
51 \\
61 \\
58 \\
49\end{array}$ & $\begin{array}{l}44 \\
53 \\
72 \\
65 \\
63\end{array}$ & $\begin{array}{l}61 \\
62 \\
64 \\
72 \\
73\end{array}$ & $\begin{array}{l}47 \\
63 \\
71 \\
75 \\
78\end{array}$ & $\begin{array}{l}62 \\
70 \\
79 \\
83 \\
83\end{array}$ \\
\hline $\begin{array}{l}\text { Racelethnicity of respondent } \\
\text { White } \ldots \ldots \ldots \ldots \ldots \ldots \ldots \ldots \ldots \\
\text { Black } \ldots \ldots \ldots \ldots \ldots \ldots \ldots \ldots \\
\text { Hispanic } \ldots \ldots \ldots \ldots \ldots \ldots \ldots \\
\text { Other }^{2} \ldots \ldots \ldots \ldots \ldots \ldots \ldots\end{array}$ & $\begin{array}{l}92 \\
75 \\
71 \\
87\end{array}$ & $\begin{array}{l}90 \\
66 \\
69 \\
86\end{array}$ & $\begin{array}{l}95 \\
80 \\
81 \\
90\end{array}$ & $\begin{array}{l}58 \\
61 \\
79 \\
71\end{array}$ & $\begin{array}{l}64 \\
80 \\
90 \\
67\end{array}$ & $\begin{array}{l}68 \\
75 \\
76 \\
63\end{array}$ & $\begin{array}{l}\text { n.a. } \\
\text { n.a. } \\
\text { n.a. } \\
\text { n.a. }\end{array}$ & $\begin{array}{l}50 \\
68 \\
86 \\
67\end{array}$ & $\begin{array}{l}61 \\
70 \\
68 \\
63\end{array}$ & $\begin{array}{l}65 \\
71 \\
63 \\
74\end{array}$ & $\begin{array}{l}70 \\
71 \\
60 \\
86\end{array}$ & $\begin{array}{l}78 \\
83 \\
66 \\
74\end{array}$ \\
\hline $\begin{array}{l}\text { Marital status of respondent } \\
\text { Married .................. } \\
\text { Single female } \ldots \ldots \ldots \ldots \ldots \\
\text { Single male } \ldots \ldots \ldots \ldots \ldots \ldots\end{array}$ & $\begin{array}{l}94 \\
83 \\
83\end{array}$ & $\begin{array}{l}90 \\
79 \\
85\end{array}$ & $\begin{array}{l}94 \\
88 \\
91\end{array}$ & $\begin{array}{l}64 \\
51 \\
60\end{array}$ & $\begin{array}{l}69 \\
64 \\
67\end{array}$ & $\begin{array}{l}71 \\
64 \\
68\end{array}$ & $\begin{array}{l}\text { n.a. } \\
\text { n.a. } \\
\text { n.a. }\end{array}$ & $\begin{array}{l}57 \\
50 \\
53\end{array}$ & $\begin{array}{l}64 \\
59 \\
59\end{array}$ & $\begin{array}{l}66 \\
70 \\
59\end{array}$ & $\begin{array}{l}75 \\
67 \\
55\end{array}$ & $\begin{array}{l}78 \\
80 \\
69\end{array}$ \\
\hline $\begin{array}{l}\text { Homeownership status } \\
\text { Own home ............. } \\
\text { Do not own home ..... }\end{array}$ & $\begin{array}{l}93 \\
80\end{array}$ & $\begin{array}{l}91 \\
74\end{array}$ & $\begin{array}{l}95 \\
84\end{array}$ & $\begin{array}{l}56 \\
69\end{array}$ & $\begin{array}{l}63 \\
78\end{array}$ & $\begin{array}{l}67 \\
77\end{array}$ & $\begin{array}{l}\text { n.a. } \\
\text { n.a. }\end{array}$ & $\begin{array}{l}50 \\
67\end{array}$ & $\begin{array}{l}59 \\
73\end{array}$ & $\begin{array}{l}70 \\
57\end{array}$ & $\begin{array}{l}72 \\
64\end{array}$ & $\begin{array}{l}78 \\
75\end{array}$ \\
\hline $\begin{array}{l}\text { Gender of respondent } \\
\text { Male..................... } \\
\text { Female........... }\end{array}$ & $\begin{array}{l}91 \\
87\end{array}$ & $\begin{array}{l}87 \\
85\end{array}$ & $\begin{array}{l}93 \\
92\end{array}$ & $\begin{array}{l}62 \\
58\end{array}$ & $\begin{array}{l}68 \\
67\end{array}$ & $\begin{array}{l}71 \\
67\end{array}$ & $\begin{array}{l}\text { n.a. } \\
\text { n.a. }\end{array}$ & $\begin{array}{l}54 \\
55\end{array}$ & $\begin{array}{l}63 \\
61\end{array}$ & $\begin{array}{l}63 \\
69\end{array}$ & $\begin{array}{l}69 \\
71\end{array}$ & $\begin{array}{l}75 \\
79\end{array}$ \\
\hline $\begin{array}{l}\text { Region } \\
\text { West ......... } \\
\text { Midwest ..... } \\
\text { Northeast..... } \\
\text { South ........ }\end{array}$ & $\begin{array}{l}91 \\
90 \\
89 \\
86\end{array}$ & $\begin{array}{l}89 \\
89 \\
83 \\
84\end{array}$ & $\begin{array}{l}94 \\
93 \\
96 \\
89\end{array}$ & $\begin{array}{l}70 \\
50 \\
60 \\
60\end{array}$ & $\begin{array}{l}73 \\
58 \\
67 \\
70\end{array}$ & $\begin{array}{l}75 \\
64 \\
76 \\
64\end{array}$ & $\begin{array}{l}\text { n.a. } \\
\text { n.a. } \\
\text { n.a. } \\
\text { n.a. }\end{array}$ & $\begin{array}{l}65 \\
47 \\
44 \\
58\end{array}$ & $\begin{array}{l}67 \\
58 \\
61 \\
62\end{array}$ & $\begin{array}{l}69 \\
62 \\
60 \\
70\end{array}$ & $\begin{array}{l}66 \\
71 \\
67 \\
74\end{array}$ & $\begin{array}{l}80 \\
74 \\
74 \\
80\end{array}$ \\
\hline
\end{tabular}

1. Income percentiles are based on the income of all responding households. Thus, of respondents in the lowest 20 percent of the income distribution, 67 percent had a bank account in 1999 and 2003 and 80 percent had a bank account in 2006

\section{Age and E-Banking}

Younger consumers (under age 35) are slightly less likely to have a bank account than consumers more typically in the workforce. However, among consumers with a bank account, the use of ATMs, debit cards, and online banking decreases consistently as age increases: younger households are much more likely than older households to use these services. The service that is the exception is direct deposit, the use of which generally increases with age. When considering changes over time, however, growth rates for adoption among older consumers (those 65 and above) have surpassed rates for other age groups. For example, the proportion of older consumers using
2. Includes Asian, Pacific Islander, and Native American. n.a. Not available.

SOURCE: Michigan Surveys of Consumers.

ATMs and preauthorized payment doubled from 1999 to 2006, the proportion using phone banking tripled, and the proportion using online banking increased tenfold.

\section{Education and E-Banking}

Consumers who have no post-secondary education are less likely than their more-educated counterparts to have a bank account. And among less-educated consumers who have a bank account, smaller proportions use e-banking services. The most widely used service among those with no post-secondary education is direct deposit, followed by prepaid cards and ATMs. 
6.-Continued

Percent

\begin{tabular}{|c|c|c|c|c|c|c|c|c|c|c|c|c|c|c|}
\hline \multicolumn{15}{|c|}{ Product or service } \\
\hline \multicolumn{3}{|c|}{ Preauthorized payment } & \multicolumn{3}{|c|}{ Phone banking } & \multicolumn{3}{|c|}{ Online banking } & \multicolumn{3}{|c|}{ Smart card } & \multicolumn{3}{|c|}{ Prepaid card } \\
\hline 1999 & 2003 & 2006 & 1999 & 2003 & 2006 & 1999 & 2003 & 2006 & 1999 & 2003 & 2006 & 1999 & 2003 & 2006 \\
\hline 31 & 46 & 57 & 40 & 44 & 46 & 10.7 & 31.9 & 51.1 & n.a. & 6 & 12 & n.a. & 73 & 73 \\
\hline 23 & 35 & 46 & 22 & 22 & 50 & 3 & 17 & 30 & n.a. & 4 & 9 & n.a. & 59 & 59 \\
\hline 21 & 39 & 50 & 30 & 47 & 43 & 6 & 27 & 38 & n.a. & 6 & 12 & n.a. & 74 & 70 \\
\hline 27 & 47 & 59 & 45 & 45 & 40 & 9 & 32 & 50 & n.a. & 5 & 10 & n.a. & 77 & 76 \\
\hline 39 & 53 & 58 & 45 & 50 & 53 & 11 & 38 & 64 & n.a. & 8 & 15 & n.a. & 79 & 76 \\
\hline 42 & 55 & 69 & 58 & 53 & 48 & 22 & 43 & 70 & n.a. & 7 & 13 & n.a. & 78 & 79 \\
\hline 25 & 47 & 62 & 45 & 53 & 50 & 16 & 48 & 67 & n.a. & 8 & 21 & n.a. & 81 & 87 \\
\hline 40 & 51 & 62 & 60 & 52 & 47 & 13 & 36 & 65 & n.a. & 6 & 8 & n.a. & 84 & 78 \\
\hline 37 & 44 & 55 & 43 & 48 & 50 & 9 & 31 & 53 & n.a. & 7 & 11 & n.a. & 73 & 73 \\
\hline 27 & 41 & 53 & 35 & 42 & 45 & 9 & 26 & 43 & n.a. & 6 & 12 & n.a. & 71 & 74 \\
\hline 26 & 44 & 52 & 11 & 18 & 36 & 2 & 9 & 20 & n.a. & 1 & 7 & n.a. & 51 & 52 \\
\hline 19 & 30 & 31 & 11 & 13 & 33 & 3 & 11 & 10 & n.a. & 3 & 3 & n.a. & 57 & 49 \\
\hline 26 & 38 & 50 & 29 & 36 & 44 & 6 & 18 & 35 & n.a. & 4 & 8 & n.a. & 68 & 63 \\
\hline 30 & 51 & 54 & 39 & 42 & 49 & 12 & 37 & 53 & n.a. & 5 & 14 & n.a. & 73 & 77 \\
\hline 37 & 51 & 60 & 56 & 55 & 48 & 15 & 41 & 59 & n.a. & 9 & 14 & n.a. & 77 & 79 \\
\hline 38 & 47 & 73 & 62 & 48 & 44 & 17 & 37 & 64 & n.a. & 7 & 14 & n.a. & 82 & 75 \\
\hline 31 & 45 & 56 & 40 & 43 & 48 & 11 & 31 & 53 & n.a. & 6 & 12 & n.a. & 74 & 74 \\
\hline 27 & 49 & 53 & 37 & 51 & 37 & 8 & 22 & 39 & n.a. & 5 & 7 & n.a. & 70 & 61 \\
\hline 38 & 49 & 65 & 44 & 51 & 50 & 11 & 36 & 51 & n.a. & 4 & 12 & n.a. & 79 & 60 \\
\hline 39 & 61 & 73 & 54 & 54 & 34 & 25 & 49 & 47 & n.a. & 16 & 12 & n.a. & 68 & 72 \\
\hline 35 & 51 & 57 & 45 & 49 & 46 & 13 & 36 & 56 & n.a. & 6 & 13 & n.a. & 77 & 76 \\
\hline 27 & 42 & 52 & 37 & 36 & 50 & 7 & 22 & 42 & n.a. & 5 & 7 & n.a. & 72 & 70 \\
\hline 25 & 33 & 49 & 30 & 38 & 40 & 11 & 33 & 45 & n.a. & 8 & 15 & n.a. & 63 & 60 \\
\hline 36 & 48 & 58 & 38 & 44 & 46 & 9 & 32 & 51 & n.a. & 6 & 10 & n.a. & 74 & 81 \\
\hline 21 & 40 & 52 & 46 & 44 & 52 & 15 & 31 & 49 & n.a. & 7 & 16 & n.a. & 71 & 68 \\
\hline 31 & 47 & 54 & 37 & 45 & 45 & 12 & 35 & 53 & n.a. & 5 & 14 & n.a. & 66 & 69 \\
\hline 31 & 46 & 59 & 43 & 43 & 48 & 10 & 29 & 49 & n.a. & 7 & 9 & n.a. & 79 & 75 \\
\hline 31 & 46 & 59 & 51 & 47 & 54 & 15 & 34 & 57 & n.a. & 6 & 8 & n.a. & 74 & 74 \\
\hline 36 & 45 & 54 & 31 & 37 & 41 & 7 & 28 & 53 & n.a. & 7 & 11 & n.a. & 74 & 69 \\
\hline 23 & 44 & 53 & 38 & 46 & 47 & 8 & 26 & 48 & n.a. & 3 & 12 & n.a. & 71 & 79 \\
\hline 31 & 48 & 60 & 42 & 47 & 45 & 12 & 36 & 48 & n.a. & 7 & 14 & n.a. & 74 & 69 \\
\hline
\end{tabular}

About one in ten of the least-educated consumers (those without a high school diploma) bank online. In 2006, 22 percent of respondents in this group had access to the Internet at home, and about 12 percent had access at work (table 3 ), hindering their ability to access and become familiar with online banking products. Thus, while an increasing percentage of less-educated consumers are using e-banking, their adoption of these services pales in comparison with consumers in other education groups. When controlling for attitudes and other demographic characteristics, education is a significant factor for the use of all e-banking technologies except phone banking.

With a few notable exceptions, between 1999 and 2006, the use of e-banking grew among most educational groups. It is interesting that respondents with the most education were less likely to report using
ATMs in 2006 than in 1999 but were more likely to report using debit cards; it may be that these consumers were substituting debit card transactions for ATM transactions. Similarly, consumers with more education appear to have switched from phone banking to online banking over time, as might be expected, as access to the Internet is also greater for those with more education.

\section{Race, Ethnicity, and E-Banking}

Compared with white consumers, lower proportions of black and Hispanic consumers report having a bank account. Over time, however, the proportions of banked black and Hispanic consumers have increased, by 5 percentage points for black households and 10 percentage points for Hispanic households from 
7. Proportion of consumers using e-banking technologies, by type of user, selected years Percent

\begin{tabular}{|c|c|c|c|c|c|c|c|c|c|}
\hline \multirow{2}{*}{ Technology } & \multicolumn{3}{|c|}{ Minimal users } & \multicolumn{3}{|c|}{ Limited users } & \multicolumn{3}{|c|}{ Early adopters and heavy users } \\
\hline & 1999 & 2003 & 2006 & 1999 & 2003 & 2006 & 1999 & 2003 & 2006 \\
\hline ATM card.. & 68 & 22 & 43 & 57 & 60 & 28 & 76 & 98 & 95 \\
\hline Debit card.. & n.a. & 7 & 38 & n.a. & 44 & 51 & n.a. & 87 & 95 \\
\hline Direct deposit .... & 31 & 63 & 51 & 100 & 62 & 83 & 34 & $\begin{array}{l}81 \\
80\end{array}$ & 86 \\
\hline Auto bill payment & 57 & 35 & 12 & 40 & 17 & 68 & 93 & 71 & 67 \\
\hline Phone banking & 18 & 34 & 11 & 58 & 17 & 38 & 57 & 67 & 59 \\
\hline Online banking . & 5 & 13 & 8 & 7 & 11 & 32 & 50 & 57 & 73 \\
\hline Prepaid card.. & n.a. & 97 & 25 & n.a. & 18 & 90 & n.a. & 92 & 83 \\
\hline All respondents. . & 37 & 29 & 22 & 48 & 26 & 26 & 15 & 45 & 51 \\
\hline
\end{tabular}

Note: Components may not sum to 100 percent because of rounding. n.a. Not available.

1999 to 2006. Among those with a bank account, black consumers appear more likely to use debit cards than their white counterparts but are less likely to bank online.

Adoption of electronic banking products and services generally seems to have increased over time for all the racial and ethnic categories surveyed. A notable exception is the use of phone banking and preauthorized payments: a substantially smaller proportion of "other" consumers (predominantly Asians, Pacific Islanders, and Native Americans) reported banking by phone in 2006 compared with previous surveys, and a substantially larger proportion of this group reported using preauthorized payments.

\section{Combinations of E-Banking Services Used by Consumers}

As e-banking has become more popular, consumers have adopted various combinations of e-banking products and services. Cluster analysis makes it possible to look at those combinations and the characteristics of the users. In general, consumers can be sorted into several groups: early adopters and heavy users, who try everything; minimal users, who use very few, if any, e-banking services; and one or more limited-user groups "in the middle," who adopt different combinations of products and services. ${ }^{16}$

Minimal users seem to make use of direct deposit and ATM and debit services (debit cards and preauthorized payments), but little else (table 7). Limited users may add phone banking to these more basic services. Heavy users are just that - they make use of most e-banking services. While it is the case that about one out of five consumers did not make much use of electronic banking services in 2006, over time

16. Hogarth, Kolodinsky, and Gabor, "Consumer Payment Choices: Paper, Plastic—or Electrons?" more than half of consumers have come to be classified as heavy users.

\section{Consumer Attitudes toward Emerging Payment Technologies}

The 2006 Michigan Surveys of Consumers asked about the use of emerging payment products, such as contactless cards and wireless payment devices. Contactless payment cards, which operate by transmitting a radio signal to a payment terminal or a handheld device (instead of by being swiped at a terminal), were not available in the United States until recently. ${ }^{17}$ In fact, only 6.3 percent of survey respondents with a bank account reported having received a contactless payment card from their bank or credit card company (data not shown). Some consumers have been exposed to contactless payments through the use of electronic pass devices at toll booths and electronic tokens at gas pumps. The main selling points of contactless payment cards are greater speed and convenience: such payments may make for faster transactions, allowing consumers to maintain control over the card rather than hand it to a merchant.

Among all respondents, more than half (52 percent) said they would or might use contactless payment cards in the future (table 8). Among online bankers (recall that they make up about 51 percent of the full sample), nearly two-thirds (65 percent) said they would or might use this means of payment.

17. The Smart Card Alliance, an industry association of payment system participants, estimates that 21 million contactless cards had been issued in the United States by April 2007. See Smart Card Alliance (2007), "Proximity Mobile Payments: Leveraging NFC and the Contactless Financial Payments Infrastructure," Smart Card Alliance Contactless Payments Council white paper (September), www.smartcardalliance.org/pages/publications-proximity-mobilepayments. 
8. Consumers' expectations regarding the use of emerging payment technologies in the future, 2006

Percent

\begin{tabular}{c|c|c|c|c|c|c}
\hline \multirow{2}{*}{ Expectation } & \multicolumn{3}{|c|}{ All respondents } & \multicolumn{3}{c}{ Respondents who bank online } \\
\cline { 2 - 7 } & Yes & Maybe & No & Yes & Maybe & No \\
\hline Use contactless payments in future $\ldots \ldots \ldots \ldots \ldots \ldots \ldots \ldots \ldots \ldots \ldots \ldots$ & 37.8 & 14.7 & 47.5 & 51.6 & 13.8 & 34.6 \\
Use wireless payments in future ..................... & 16.3 & 7.2 & 76.5 & 24.0 & 7.7 & 68.2 \\
\hline
\end{tabular}

NoTE: Components may not sum to 100 because of rounding.

The future success of contactless payments may be tied to the same demographic characteristics that appear to influence adoption of other electronic banking products. Income, age, education, and race and ethnicity, for example, appear to be associated with the adoption of electronic banking products. Similarly, consumers with higher income and more education, and younger households, were more likely to indicate a willingness to use contactless payment products in the future (see appendix table B.2).

Wireless payment devices were described in the survey as cellular phones and PDAs that can be equipped with a computer chip that allows users to charge items to their phone bill using the device instead of to a credit or debit card. Applications are also being developed, in a partnership between banks and telecommunications companies, that will debit users' bank account or bill their credit card account rather than charge their phone bill.

Compared with contactless payments, the potential success of other types of wireless payment devices is much less clear. The majority of respondents to the 2006 Michigan Surveys of Consumers (77 percent) said they were unlikely to use wireless payments in the future, and consumers who reported banking online were only slightly more likely to say they would likely adopt wireless payment technology.

What accounts for this difference between consumers' willingness to use contactless and wireless payments? Some researchers suggest that consumers do not necessarily see a need for wireless products. ${ }^{18}$ Moreover, as is the case with contactless cards, familiarity with these products is directly related to their availability, and the infrastructure enabling merchant acceptance of contactless and wireless cards is still developing in the United States. To date, wireless payments systems have been deployed in parts of Europe and Asia but still face significant technological and infrastructural barriers in the United States.

Mobile banking and payments, via such devices as mobile (or "cell") phones and PDAs, have gained attention in recent years (see box "Mobile Banking

18. Dan Schatt (2007), US Mobile Banking: Beyond the Buzz (Boston: Celent).
SourCE: Michigan Surveys of Consumers.

and Payments"). Access to mobile technology is now widespread in the United States; an estimated 80 percent of the population have access to mobile phones, and some industry analysts predict that mobile phone use in the United States will approach 100 percent in a few years. ${ }^{19}$ As of early 2009, all the major financial institutions in the United States offer mobile banking services that provide account access via mobile phones and PDAs, and many smaller banks are adding technologies to provide mobile banking services. ${ }^{20}$ These services generally allow consumers to transfer funds between accounts, schedule online payments, and conduct other online banking transactions using their mobile device, but most do not allow consumers to use their mobile device to make payments at the point of sale. Third-party providers are beginning to offer mobile payment options using short message service (SMS) technology, and niche markets, such as the Metropolitan Transit Authority in New York City, are using near-field communication (NFC) chip technology to enable payments. ${ }^{21}$

Before mobile payments can become more widespread and accepted by both merchants and consumers, financial institutions, mobile carriers, mobile hardware producers, and other stakeholders must cooperate to develop standards that will allow interoperability among mobile devices and bank technology networks. Although adoption has already occurred in Asia and Europe, most industry insiders believe it will take several years, perhaps until 2012, for mobile payments to become widespread in the United States. ${ }^{22}$ However, the recent rapid adop-

19. Joseph Salesky (2007), "Mobile-Phone Banking: Coming to a Bank Near You," U.S. Banker (July), www.americanbanker.com/ usb_article.html?id=20070626A2K9LH3P.

20. Marianne Crowe (2008), Emerging Payments-The Changing Landscape, Presentation to Maine Association of Community Banks and New Hampshire Community Bankers Association (Boston: Federal Reserve Bank of Boston, April), www.bos.frb.org/economic/eprg/ presentations/2008/crowe04151708.pdf.

21. Nasreen Quibria (2008), The Contactless Wave: A Case Study in Transit Payments, Emerging Payments Industry Briefing (Boston: Federal Reserve Bank of Boston, June), www.bos.frb.org/economic/ eprg/papers/briefings/transit.pdf.

22. According to the 2007 Mobile Financial Services Study, 51 percent of survey respondents believe mobile payments will be a reality in five to ten years, while 20 percent expect it to take more than ten years. 


\section{Mobile Banking and Payments}

In Zagreb, Croatia, consumers can board the local streetcar and pay their fare via their mobile phone. In Kuala Lumpur, Malaysia, consumers can use their mobile phone to pay for parking and restaurant meals. In Stockholm, Sweden, consumers can buy a cup of coffee using their mobile phone.

Technologies using mobile (or "cell") phones, PDAs, and other wireless handheld devices are also making an appearance in the U.S. financial services market, initially as mobile banking. The recent implementation of programs at major U.S. financial institutions, coupled with the emergence of pilot programs at many regional and local banks, indicates that mobile banking is about to become a widely accepted banking medium. Industry experts believe that the evolution in mobile technology, together with consumer demand for more-convenient access to their banks' products and services, especially among younger generations, will create a viable market for mobile banking.

Mobile banking is a logical extension of online banking and thus may be a comfortable next step for online bankers. But extending the use of mobile devices beyond banking transactions to point-of-sale and person-toperson fund transfers may require innovations in merchant, telecommunication, and financial services infrastructure as well as consumer willingness to try new payment technologies.

\section{Technology behind Mobile Banking and Payments}

Currently, mobile banking and transactions rely on one of several basic technologies:

- web access protocol (WAP) - a technology generally used for mobile banking; has the familiar look and feel of online banking

- downloadable application-a technology that allows users to download the platform needed for a transaction; look and feel of platforms similar to online banking
- short message service (SMS) — a technology that leverages text messaging to monitor account balances and authorize and track payments; widely considered to be the fastest growing and most popular platform at present

- near-field communication (NFC) chip-a computer chip similar to those found in contactless payment cards. In 2006, New York's Metropolitan Transit Authority (MTA) implemented a pilot program for using contactless cards to pay fares and, a few months into the trial, added NFC-enabled mobile phone payments as an alternative to card payments. The early response was positive, with the MTA reporting that customer acceptance was good, there were no consumer complaints about MTA charges, no instances in which the MTA had to return funds to a consumer, and no fraud. ${ }^{1}$

Companies adopting mobile payment technology now include nontraditional banking institutions and thirdparty payment providers such as PayPal, Obopay, and Amazon. The industry is also looking at GPS technology in mobile phones to allow customers to locate financial products and services (such as ATMs) and to identify targeted promotions when they are within a reasonable distance of products and services that might be of interest to them.

The "electronic wallet" (stored, encrypted credit card or bank account information that can be used to make electronic payments without entering the information for each transaction), which was developed for online transactions, is also being adapted for mobile devices and dubbed the "m-wallet." The m-wallet will include downloadable applications to enable customers to manage routine financial transactions, including both debit and

1. Nasreen Quibria (2008), The Contactless Wave: A Case Study in Transit Payments, Emerging Payments Industry Briefing (Boston: Federal Reserve Bank of Boston, June), www.bos.frb.org/economic/eprg/papers/ briefings/transit.pdf. tion of smartphone technology may serve to expedite the process (a smartphone is a mobile phone with advanced features, often with PC-like functionality).

Insights provided by the Diffusion of Innovation model and the Technology Acceptance Model (described in the next section) suggest that consumers'

See Edgar, Dunn \& Company (2007), 2007 Mobile Financial Services Study: Key Findings Report (San Francisco: Edgar, Dunn \& Company, February). familiarity with mobile devices, along with additional experience with text messaging technology (SMS), contactless payment cards, and wireless Internet, will speed the adoption of a variety of mobile banking technologies. Online banking and contactless payments may be the building blocks for further adoption. $^{23}$

23. Julia S. Cheney (2008), "An Examination of Mobile Banking and Mobile Payments: Building Adoption as Experience Goods?" Payment Cards Center Discussion Paper 08-06 (Philadelphia: Federal 
credit transactions, and conduct routine banking functions. One vendor promotes an m-wallet product that includes bill payment, prepaid airtime replenishment, prepaid shopping cards, money orders, money transfers, coupons, person-to-person transactions, gift/loyalty cards, ticketing, and point-of-sale transactions. ${ }^{2}$ The evolution and adoption of "smartphone" technology has provided a solid platform for developing, launching, and marketing applications for those functions.

\section{Anticipated Adoption}

Market reports indicate that despite earlier failures in introducing mobile banking products and services, demand may finally be sufficient to support mobile commerce. One report predicts that 30 percent of online banking households will use mobile banking by the end of $2010 .^{3}$ In a survey described in the report, 50 percent of the Generation $\mathrm{Y}$ cohort (defined as persons age 18-25) indicated that they considered the availability of mobile banking a "very important" or "somewhat important" factor when choosing a financial institution; 84 percent of this group (the early adopters of mobile banking technology) said they already use their mobile phone for functions other than making calls.

The features of mobile commerce that are attractive to consumers are similar to those of online banking, namely, convenience and ease of use. In addition, mobile commerce enables consumers to access their accounts from almost anywhere at almost any time. Immediate access to account balances and overdraft alerts have the potential to enable consumers to exercise responsible control over their finances. In a recent consumer trial of mobile banking products, 75 percent of participants thought that mobile banking allowed them to make better-informed spending decisions, and more than 50 percent reported

2. Motorola, Inc. (2008), "Motorola M-Wallet Solution: New Transaction Options for Subscribers, New Revenue Opportunities for You" (brochure), www.motorola.com/staticfiles/Business/_Documents/ static\%20files/M-Wallet_BRO_0608_chv2.pdf.

3. Dan Schatt (2007), US Mobile Banking: Beyond the Buzz (Boston: Celent). an increase in the amount of control they had over their finances. ${ }^{4}$

Businesses providing these services may be able to capture the unmet demand for banking products and services among the unbanked and underbanked-groups that, according to the Center for Financial Services Innovations (CFSI), account for nearly 40 percent of U.S. households. CFSI believes that widespread use of alternative service providers (such as payday lenders and check cashers) and the fact that approximately 65 percent of Americans own a mobile phone are indications of potential demand. ${ }^{5}$

\section{Barriers to Adoption: Infrastructure and Security}

Among the factors hindering adoption of mobile banking and commerce is the lack of infrastructure that can optimize the functionality of these products. Key challenges to service providers lie in providing ease of use and interoperability - features crucial to widespread adoption. The current generation of mobile products and services appears to be functioning efficiently without set standards for interoperability. SMS technology is leading the way. However, the next generation, which is expected to rely on a combination of SMS technology and downloadable applications (in many cases relying heavily on the adoption of smartphone technology), has greater infrastructure requirements. Service providers also face the challenge of persuading potential customers that their products and services are safe and secure. The data on online banking analyzed for this article indicate that a perception of safety is an important consideration in adoption. Consumer concerns include customer authentication (verification that the user is in fact the authorized user), the interception of private data, and the loss of sensitive information if the mobile device is lost or stolen.

4. Michael Lindsey (2008), "Mobile Banking Case Study: Lessons Learned from a Pilot Rollout," NACHA Teleseminar: Case Studies from Bank Mobile Implementations.

5. Caroline Boyd and Katy Jacob (2007), Mobile Financial Services and the Underbanked: Opportunities and Challenges for Mbanking and Mpayments (Chicago: Center for Financial Services Innovation, April), www.cfsinnovation.com/document/mbanking.pdf.
In addition to issues of access, availability, and familiarity, there are concerns about the security and privacy of financial information related to contactless card, wireless, and mobile transactions. These concerns may be the greatest impediments to the success of mobile banking, wireless, and contactless payments. A 2007 report noted that 82 percent of surveyed banks thought resolving security issues was "important or very important to resolve for successful mobile banking." 24 
9. Consumers' perceptions of e-banking, selected years

\begin{tabular}{|c|c|c|c|c|c|c|}
\hline \multirow{2}{*}{ Perception } & \multicolumn{3}{|c|}{ Mean of responses ${ }^{1}$} & \multicolumn{3}{|c|}{ Percent who agree or strongly agree } \\
\hline & 1999 & 2003 & 2006 & 1999 & 2003 & 2006 \\
\hline \multicolumn{7}{|l|}{ Convenience } \\
\hline Electronic banking is convenient.. & 3.8 & 3.9 & 4.0 & 76 & 81 & 80 \\
\hline There are enough advantages of electronic banking for me to & & & & & & \\
\hline $\begin{array}{l}\text { consider using it } \ldots \ldots \ldots \ldots \ldots \ldots \ldots \ldots \ldots \ldots \ldots \ldots \ldots \ldots \ldots \ldots \ldots \ldots \ldots \ldots \ldots \\
\text { Electronic banking helps me to better manage my personal finances }\end{array}$ & 3.1 & $\begin{array}{l}3.4 \\
3.3\end{array}$ & 3.4 & 46 & $\begin{array}{r}58 \\
48\end{array}$ & 56 \\
\hline It bothers me to use a machine for banking transactions when & 3.0 & 3.3 & 3.3 & 37 & 48 & 50 \\
\hline 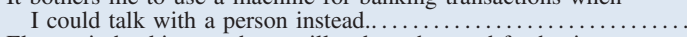 & 3.2 & 3.1 & 2.9 & 53 & 46 & 42 \\
\hline $\begin{array}{l}\text { Electronic banking products will reduce the need for having } \\
\text { traditional bank accounts in the future. } \ldots \ldots \ldots \ldots \ldots \ldots \ldots\end{array}$ & n.a. & n.a. & 3.4 & n.a. & n.a. & 53 \\
\hline \multicolumn{7}{|l|}{ Familiarity and ease of use } \\
\hline Electronic banking is the wave of the future... & 3.8 & 4.0 & 3.9 & 72 & 82 & 74 \\
\hline Electronic banking services are used by many people. ..... & 3.7 & 3.9 & 3.9 & 70 & 83 & 80 \\
\hline I have the opportunity to try various electronic banking services.. & 3.1 & 3.6 & 3.5 & 49 & 70 & 64 \\
\hline I have seen how others use electronic banking................. & 3.0 & 3.5 & 3.4 & 41 & 64 & 57 \\
\hline I need to familiarize myself with electronic banking technology. . & 3.5 & 3.3 & 3.4 & 63 & 53 & 57 \\
\hline Electronic banking is difficult to use. ......................... & 2.6 & 2.5 & 2.3 & 21 & 17 & 15 \\
\hline 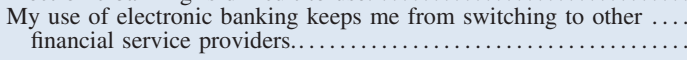 & n.a. & n.a. & 2.8 & n.a. & n.a. & 28 \\
\hline \multicolumn{7}{|l|}{ Security and privacy } \\
\hline 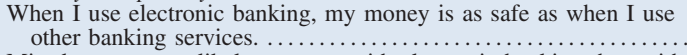 & 3.2 & 3.3 & 3.4 & 49 & 55 & 54 \\
\hline 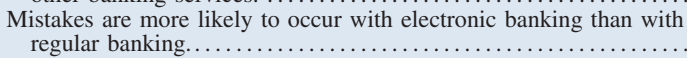 & 3.0 & 2.9 & 2.9 & 41 & 36 & 31 \\
\hline 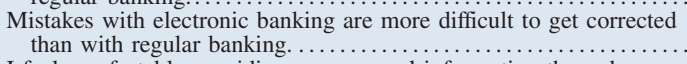 & 3.3 & 3.3 & 3.2 & 50 & 49 & 45 \\
\hline $\begin{array}{l}\text { I feel comfortable providing my personal information through } \\
\text { electronic banking systems. }\end{array}$ & 2.7 & 2.9 & 2.9 & 35 & 41 & 40 \\
\hline I worry about the privacy of my information when using electronic & & & & & & \\
\hline 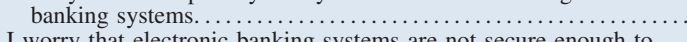 & n.a. & 3.5 & n.a. & n.a. & 63 & n.a. \\
\hline $\begin{array}{l}\text { I worry that electronic banking systems are not secure enough to } \\
\text { protect my personal financial information. ....................... }\end{array}$ & n.a. & 3.2 & 3.3 & n.a. & 52 & 52 \\
\hline I worry that electronic banking systems are not secure enough and & & & & & & \\
\hline $\begin{array}{l}\text { I could lose my money.................................................. } \\
\text { Electronic banking increases the likelihood that I will become a }\end{array}$ & n.a. & 3.0 & 3.1 & n.a. & 40 & 46 \\
\hline 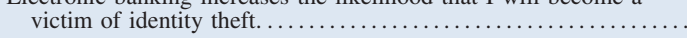 & n.a. & n.a. & 3.5 & n.a. & n.a. & 60 \\
\hline
\end{tabular}

1. On a scale of 1 to 5 , with 1 being "strongly disagree," 3 "neutral," and 5 "strongly agree."

n.a. Not available.

SouRCE: Michigan Surveys of Consumers.

based on the TAM and its extensions has found consistently positive relationships between usefulness, and to a lesser extent ease of use, and the adoption of a variety of technologies, including computer software and e-mail. ${ }^{26}$

\section{Convenience}

Overall, research indicates that the more observable, compatible, simple, and useful a technology is and the more advantages it offers, the more likely consumers are to adopt it. Consumers continue to recognize the convenience of electronic banking services (table 9). ${ }^{27}$ As measured by the 1999, 2003, and 2006 Michigan Surveys of Consumers, growing proportions of consumers report that e-banking helps them better manage their personal finances, and smaller proportions report being bothered by not interacting

26. Hogarth, Kolodinsky, and Gabor, "Consumer Payment Choices: Paper, Plastic —or Electrons?'

27. In a 2007 study by the Federal Reserve Bank of Boston, both users and nonusers recognized the convenience of e-banking services (Benton, Blair, Crowe, and Schuh, "The Boston Fed Study of Consumer Behavior and Payment Choice").
25. Everett M. Rogers (1962), The Diffusion of Innovation
New York: Free Press); Frederick D. Davis (1989), "Perceived Usefulness, Perceived Ease of Use, and User Acceptance of Information Technology," MIS Quarterly, vol. 13, pp. 319-40. 
with people in their banking transactions. A new question in the 2006 survey asked about the need for traditional bank accounts; more than half of respondents (53 percent) said that e-banking products will reduce the need.

\section{Familiarity and Ease of Use}

Consumers' perceptions regarding familiarity and ease of use of e-banking technology, as reported in the 2006 Michigan Surveys of Consumers, reveal an interesting dichotomy (table 9). On the one hand, the majority reported that e-banking is widely used (80 percent) and that they have seen how others use it (57 percent). On the other hand, nearly three out of five (57 percent) felt that they need to become more familiar with e-banking services. Clearly there is a need for bankers and community educators to find out which aspects of e-banking are unfamiliar to consumers and to craft outreach and education opportunities to address information gaps.

E-banking can be perceived as a set of services that engenders loyalty in a customer base. Once consumers have signed up for direct deposit, online banking, or preauthorized payment, they may perceive the transition costs involved in switching banks-in terms of both time and mental energy - as quite high. However, only about one-fourth (28 percent) of survey respondents felt that their use of electronic banking keeps them from switching to another financial services provider. The message to financial institutions is clear-even e-bankers feel empowered to vote with their feet.

\section{Security and Privacy}

Consumers also report disparate perceptions with respect to security and privacy. Over time, the proportions of consumers expressing concern about mistakes connected with e-banking and about difficulty in resolving errors have declined. In addition, more than half the respondents to the 2006 Michigan Surveys of Consumers (54 percent) reported feeling that e-banking was "as safe as when I use other banking services." However, more than half (52 percent) were concerned that e-banking systems were not secure enough to protect their personal financial information, and three out of five (60 percent) agreed or strongly agreed that e-banking would increase the likelihood of their becoming a victim of identity theft (table 9).

These results are consistent with related findings from other studies. For example, between 2005 and 2007 consumers' concerns about online security decreased and the percentage of consumers paying their bills online increased, yet data on Internet transactions by payment type show that the proportion of credit card payments declined over the same period. ${ }^{28}$ One interpretation is that the decline in Internet credit card transactions reflects consumers' concerns about security. Analysis of the adoption of Internet banking in Poland found a relationship between the decision to open an online account and the perceived level of security of Internet transactions: a 1 percentage point decrease in perceived security was associated with a drop of almost 29 percent in the probability of opening an online account. ${ }^{29}$ A 2007 study by the Boston Federal Reserve Bank also found that the main barriers to using online bill payment were concerns about privacy and identity theft. ${ }^{30}$

Increasingly, consumers are targeted with computer viruses, spam, and phishing e-mail messages that attempt to steal their personal information. Data security requires providing security for data at rest (data residing on computers within organizations), data in transit (data moving over networks), and data "on travel" (data on laptops or other portable devices). ${ }^{31}$ Reports of data breaches involving consumers' names, account numbers, and other information have received attention from state and federal lawmakers. In mid-2003, California became the first state to require businesses to notify consumers of data breaches that result in the loss of their personal information. ${ }^{32}$ Since then, all but six states have enacted laws requiring notification of data breaches. ${ }^{33}$ Before these notification laws took effect, news reports of breaches were infrequent; after 2003, public announcements became much more frequent (figure 2). ${ }^{34}$

28. Crowe, Emerging Payments-The Changing Landscape.

29. Polasik and Wisniewski, "Empirical Analysis of Internet Banking Adoption in Poland."

30. Benton, Blair, Crowe, and Schuh, "The Boston Fed Study of Consumer Behavior and Payment Choice."

31. Bruce Summers, cited in James C. McGrath and Ann Kjos (2006), "Information Security, Data Breaches, and Protecting Cardholder Information: Facing Up to the Challenges," Summary of Payment Cards Center and Electronic Funds Transfer Association conference, September 2006 (Philadelphia: Federal Reserve Bank of Philadelphia), www.philadelphiafed.org/pcc/conferences/2007/ C2006SeptInfoSecuritySummary.pdf.

32. California implemented the law in 2003. See the California civil code, section 1798.80-1798.84.

33. National Conference of State Legislatures, "State Security Breach Notification Laws," December 16, 2008, www.ncsl.org/ programs/lis/cip/priv/breachlaws.htm.

34. Several very large data breaches (not included in figure 2) came to light as a result of the notification laws, including the loss of 40 million records by MasterCard reported in 2005; 26.5 million records by the Veterans Administration reported in 2006; and more 
2. Number of consumer data records reported lost per month, 2000-2007

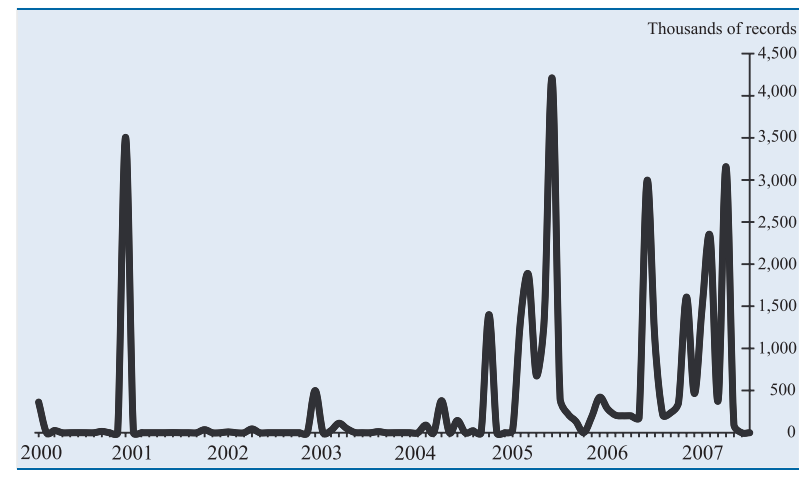

Note: Excludes data losses exceeding 4 million records, including a loss of 40 million records reported in 2005 by MasterCard; a loss of 26.5 million records reported in 2006 by the Veterans Administration; and a loss of more than 94 million records exposed in a data breach at the TJMaxx parent company reported in 2007.

Source: Rita Tehan (2007), "Data Security Breaches: Context and Index Summaries," Congressional Research Service Report RL33199 (May 7), www.fas.org/sgp/crs/misc/RL33199.pdf.

Some observers claim that a very small percentage of data breaches actually result in fraud. ${ }^{35}$ Nevertheless, notification may make consumers better off, because they are better able to protect themselves against fraudulent use of their personal financial information. In some instances, consumers whose data have been breached are provided with credit monitoring services, whereby one of the credit reporting agencies alerts them whenever their credit file is accessed. Consumers may also be able to place a fraud alert on their credit file or freeze their credit file altogether, preventing anyone but themselves from using their personal financial information to obtain credit. (See box "Reducing the Risks from Identity Theft.")

Despite indications that the number of identity theft incidents is declining, the media continue to pay significant attention to data losses-possibly increasing consumer concern about security and privacy. ${ }^{36}$ Studies by the Congressional Research Service estimate total data losses between 2000 and 2007 to have been 100 million records, not including losses exceeding 4 million records or incidents in which the number of losses is unknown (figure 2). The Privacy

than 94 million records by TJX, parent company of TJMaxx and Marshalls, reported in 2007.

35. A Javelin Strategy and Research study showed that fewer than 1 percent of lost data records result in fraudulent activities (Mary T. Monahan (2006), "Data Breaches and Identity Fraud: Misunderstanding Could Fail Consumers and Burden Businesses" (August)).

36. The number of identity theft victims declined from an estimated 8.9 million adults in 2005 to an estimated 8.4 million adults in 2006 (Javelin Strategy and Research, 2007 Identity Fraud Survey Report (February 2007), as cited on the Privacy Rights Clearinghouse website, www.privacyrights.org/ar/idtheftsurveys.htm\#Jav2007).
10. Probability of being a heavy user of e-banking technologies, by consumer attitude toward aspects of e-banking, 2003

\begin{tabular}{|c|c|c|c|}
\hline \multirow[b]{2}{*}{ Aspect } & \multicolumn{3}{|c|}{ Attitude } \\
\hline & $\begin{array}{l}\text { Highly } \\
\text { positive }\end{array}$ & $\begin{array}{l}\text { Middle of } \\
\text { the road }\end{array}$ & $\begin{array}{c}\text { Highly } \\
\text { negative }\end{array}$ \\
\hline Security and privacy. & .80 & .70 & .45 \\
\hline Convenience ......... & .84 & .57 & .35 \\
\hline Familiarity and ease of use. & .77 & .56 & .26 \\
\hline
\end{tabular}

Source: Hogarth, Kolodinsky, and Gabor, "Consumer Payment Choices: Paper, Plastic_-or Electrons?" (based on 2003 Michigan Surveys of Consumers data).

Rights Clearinghouse identified incidents occurring between January 2005 and April 2009 that resulted in more than 253 million lost or stolen records. ${ }^{37}$

In 2003, three out of five consumers (63 percent) reported being worried about the privacy of their consumer information when banking electronically, and in 2006 about the same proportion (60 percent) felt that e-banking would increase the likelihood of their becoming an identity theft victim (table 9). The large number of data losses-whether or not they result in fraud-may be contributing to consumers' concerns. Looking to the future, some research suggests that improvements to hardware and to software authentication techniques could be effective in reducing identity theft, augmenting the current practice of relying on fixed passwords, which most banks use for their online services.

\section{The Importance of Attitudes}

When other key variables-such as income, age, education, marital status, race and ethnicity, gender, and region-are held constant, attitudes become important predictors of consumers' adoption of e-banking technologies. It appears, for example, that increasing consumer confidence in the security and privacy of various technologies could bring about a large increase in their use: in the 2003 Michigan Surveys of Consumers, respondents with highly positive perceptions of e-banking's security and privacy had an 80 percent probability of using a full range of the technologies, compared with a 45 percent probability for those with highly negative perceptions (table 10). To improve consumer attitudes, financial institutions may want to consider ways of providing evidence of the security and privacy of their electronic payment services, although changing consumers' perceptions may be a challenge when phishing and identity theft continue to be in the news.

37. Privacy Rights Clearinghouse, "A Chronology of Data Breaches," updated April 9, 2009, www.privacyrights.org/ar/ ChronDataBreaches.htm. 


\section{Reducing the Risks from Identity Theft}

Technology offers some help to consumers in reducing the consequences of identity theft. For example, electronic banking technologies allow them to monitor their account activity, thereby helping them identify fraudulent activities sooner than they otherwise might. The financial industry also benefits from technological innovations, for example, modeling techniques that monitor account activity and identify anomalies associated with potentially fraudulent transactions.

Consumer liability in the event of identity theft (as well as credit card theft) is limited both by state and federal regulations that protect consumers and by industry rules. Credit card users in particular are protected by the Truth in Lending Act and the Federal Reserve Board's Regulation Z, which limit their liability for unauthorized transactions to $\$ 50$. In addition, the Electronic Fund Transfer Act and the Board's Regulation E specify liability limits for unauthorized electronic transactions and set forth procedures for recouping funds stolen from consumers' bank accounts. The limits are $\$ 50$ if the consumer notifies the bank within 2 days of learning of the loss or theft of a debit card and up to $\$ 500$ if the consumer notifies the bank after 2 days but within 60 days after the bank sends a statement containing an unauthorized transfer or transaction. Consumers who do not report an unauthorized transfer appearing on a statement within 60 days after the statement is sent risk unlimited loss on their account plus the maximum amount of their overdraft line of credit, if any. Some debit and credit card issuers guarantee that a consumer will not be held responsible for fraudulent charges incurred with the consumer's card or account information.

Consumers who are victims of identity theft should take the following steps, as laid out on the Federal Trade Commission's website:

1. Contact the credit reporting companies, place a fraud alert on your credit reports, and review your credit reports.

- Equifax. 1-800-525-6285; www.equifax.com; P.O. Box 740241, Atlanta, GA 30374-0241
- Experian. 1-888-EXPERIAN (1-888-397-3742); www.experian.com; P.O. Box 9532, Allen, TX 75013

- TransUnion. 1-800-680-7289; www.transunion. com; Fraud Victim Assistance Division, P.O. Box 6790, Fullerton, CA 92834-6790

2. Close the accounts that you know, or believe, have been tampered with or opened fraudulently.

3. File a complaint with the Federal Trade Commission. Use the FTC's online complaint form (www. ftccomplaintassistant.gov/); or call the FTC's Identity Theft Hotline, toll-free, at 1-877-ID-THEFT (1-877438-4338); TTY: 1-866-653-4261; or write to the Identity Theft Clearinghouse, Federal Trade Commission, 600 Pennsylvania Avenue NW, Washington, DC 20580.

4. File a report with your local police or the police in the community where the identity theft took place. If the police are reluctant to take your report, ask to file a "miscellaneous incident" report, or try another authority, such as your state police. You can also check with your state attorney general's office to find out if state law requires the police to take reports for identity theft. Check the Blue Pages of your telephone directory for the phone number, or check www.naag.org for a list of state attorneys general.

The FTC encourages consumers to take the following precautions to guard against identity theft:

- Deter identity thieves by safeguarding your information, including your social security number and account numbers.

- Detect suspicious activity by routinely monitoring your financial accounts, billing statements, and credit reports.

- Defend against identity theft as soon as you suspect it by taking the four steps listed above.

For more information, visit www.ftc.gov/bcp/edu/ microsites/idtheft/ and www.bos.frb.org/consumer/ identity/index.htm.
Similarly, changing consumer attitudes about the convenience of e-banking technologies could bolster their use. In the 2003 survey, consumers with highly positive perceptions of the convenience of e-banking were more than twice as likely as those with negative perceptions to adopt a wider range of e-banking services. Both financial institutions and communitybased educators can help consumers identify ways in which payment technologies can make bill paying more convenient. For example, they might point out that using preauthorized payments ensures that bills are paid on time, thus eliminating late fees.

Increasing familiarity and ease of use may offer the greatest potential for increasing adoption of e-banking technologies. The data reviewed in this article indicate that helping people access and become more familiar with these technologies and demonstrating their ease of use could lead to as much as a 51 per- 


\section{Policy Challenges and Opportunities}

Policymakers face several challenges in the e-banking market, including providing data security and consumer protection and regulating the involved entities.

Federal, state, and local laws set the basic parameters for data security; industry best practices and individual firms' policies also require certain data security safeguards. However, as new products and services evolve, laws, regulations, and policies often struggle to keep up with the evolving risks. Also, the once-clear definition of who is a financial services provider has become blurred as nonbank providers such as telecommunications firms and other third parties have moved into the market and are now providing payment services and financial transfers. Multiple regulators and regulations may be involved in a single transaction.

Related to the blurring of regulatory lines are the matters of consumer protection and avenues of recourse. Although it is possible for consumers to receive disclosures via a handheld device-a PDA or mobile phonequestions remain. Is the screen large enough for consum- ers to see the required disclosures "clearly and conspicuously"? Can financial services providers group the required information together on a small screen so that consumers can take in the meaning? What is a consumer's recourse if a mobile transaction goes awry? Does the consumer contact the mobile provider or the financial institution, or both?

The entry of nonbank providers into the financial services market presents another set of challenges. Some legislation, such as the Truth in Lending Act, makes it clear that the law and associated regulations cover nonbank entities. But coverage under other laws and regulations is less clear. Some have argued that the regulatory environment needs to be updated to reflect new and emerging technologies and relationships. ${ }^{1}$

1. Gail Hillebrand (2008), "Before the Grand Rethinking: Five Things to Do Today with Payments Law and Ten Principles to Guide New Payments Products and New Payments Law," Chicago-Kent Law Review, vol. 83 (2), pp. 769-811. centage point increase (from 26 percent to 77 percent) in the probability of adopting more of these technologies.

\section{EXPANSION OF E-BANKING}

Expansion of e-banking is a matter of both supply and demand. On the supply side, merchant acceptance seems to be key to expanding from magnetic stripe technologies to radio-frequency, smart-card, and other chip-based technologies. Fee structures and payment streams for issuers, merchants, and consumers are also important. ${ }^{38}$ On the demand side, consumer access - a payment infrastructure that provides e-banking services and broad consumer ability to bank electronically_and positive consumer attitudes are essential to wider adoption of e-banking.

Expanding access through improved infrastructure does not have to rely on extreme technological solutions. A first step may be to continue to reduce the persistent digital divide between upper- and lowerincome households. One approach is to increase access to high-speed Internet connections. Another is to expand the availability of phone banking, both through improved and expanded automated systems

38. Margaret Carten, Dan Littman, Scott Schuh, and Joanna Stavins (2007), "Consumer Behavior and Payment Choice: 2006 Conference Summary," Public Policy Discussion Paper 07-4 (Boston: Federal Reserve Bank of Boston), www.bos.frb.org/economic/ppdp/2007/ ppdp0704.pdf. that can act as substitutes for online banking and through improved web access protocols for mobile phone banking. These are natural extensions of current trends; financial institutions may want to do even more to provide and promote alternative ways of banking.

However, expanding e-banking may not be a case of "if you build it, they will come." While the proportion of heavy users of e-banking has increased over time, more than one out of five survey respondents in 2006 (22 percent) were classified as minimal users, making use of only direct deposit and ATM or debit cards. The data suggest that attitudes may play an important role in expanding adoption. Consumers need to perceive that e-banking is safe and that their information is secure. Both financial institutions and policymakers have a role in ensuring a safe data environment for e-banking (see box "Policy Challenges and Opportunities"). Beyond safety, consumers need to perceive that e-banking is convenient and easy to use. As policymakers and financial institutions continue to address the issues of access and attitudes, consumers can fully realize the potential of e-banking to help them manage their payments and increase their financial security.

\section{APPENDIX A: SOURCES OF DATA}

The data on which this article is based come from two nationally representative surveys - the triennial Sur- 
vey of Consumer Finances and the monthly Michigan Surveys of Consumers. Although the surveys have different sampling schemes and differ in some other ways, the data from the two are sufficiently comparable to give a general picture of consumer use and perceptions of electronic banking technologies. Data from the two surveys were not combined for analysis; rather, a separate analysis was carried out on each data set, and the results in some discussions were viewed together to extend the period of analysis and thus get a better idea about trends.

In general, the terms households, consumers, families, and respondents are used interchangeably in discussions of the data and elsewhere in the article. To be specific, however, data from the Survey of Consumer Finances are for what was referred to as the primary economic unit, defined as an economically dominant single individual or couple (married or living as partners) in a household and all other individuals in the household who are financially dependent on that individual or couple. For example, in the case of a household composed of a married couple who own their home, a minor child, a dependent adult child, and a financially independent parent of one of the members of the couple, the primary economic unit would be the couple and the two children. Data from the Michigan Surveys of Consumers are for families, defined as any group of persons living together who are related by marriage, blood, or adoption or any individual living alone or with a person or persons to whom the individual is not related.

\section{Survey of Consumer Finances}

The Survey of Consumer Finances (SCF) is a triennial survey of U.S. families (defined as primary economic units, as described above) sponsored by the Federal Reserve, in cooperation with the Statistics of Income Division of the Internal Revenue Service, and conducted by NORC, a national organization for research at the University of Chicago. ${ }^{39}$ The survey provides detailed information on U.S. families' balance sheets, use of financial services, demographics, and labor force participation. The great majority of interviews were conducted in person, although interviewers were allowed to conduct telephone interviews if that was more convenient for the respondent.

39. See Arthur B. Kennickell (2000), ',Wealth Measurement in the Survey of Consumer Finances: Methodology and Directions for Future Research", (paper prepared for the annual meetings of the American Association for Public Opinion Research, Portland, Oregon, May 2000) (www.federalreserve.gov/pubs/oss/oss2/papers/measurement. pdf and references cited therein).
Interviewers used a program running on laptop computers to administer the survey and collect the data. Respondents were encouraged to consult their records as necessary during the interviews.

To gather information that is both representative of the U.S. population and reliable for those assets concentrated in affluent households, the SCF employs a dual-frame sample design consisting of a standard, geographically based random sample and an oversample of affluent households. Weights are used to combine data from the two samples so that the data from the sample families represent the population of all families. ${ }^{40}$ A total of 4,299 households (representing 99.0 million families) were interviewed for the 1995 survey; 4,309 households (representing 102.6 million families) for the 1998 survey; 4,449 households (representing 106.5 million families) for the 2001 survey; 4,522 households (representing 112.1 million families) for the 2004 survey; and 4,422 households (representing 116.1 million families) for the 2007 survey. Missing data-missing because of lack of response to individual interview questions, for example - are imputed by making multiple estimates of the missing data to allow for an estimate of uncertainty.

The analysis was restricted to those households that reported having an account with a bank, thrift institution, or credit union. For the 1995 survey, this group constituted 87.6 percent of households; for the 1998 survey, 90.5 percent; for the 2001 survey, 90.9 percent; for the 2004 survey, 91.3 percent; and for the 2007 survey, 92.1 percent.

\section{University of Michigan \\ Surveys of Consumers}

The Surveys of Consumers, initiated in the late 1940s by the Survey Research Center at the University of Michigan, measure changes in consumer attitudes and expectations with regard to consumer finance decisions. ${ }^{41}$ Each monthly survey of about 500 households includes a set of core questions. For the October and November 1999, June and July 2003, and November and December 2006 surveys, the Federal Reserve Board commissioned additional questions concerning households' use and perceptions of electronic bank-

40. See Arthur B. Kennickell (1999), "Revisions to the SCF Weighting Methodology: Accounting for Race/Ethnicity and Homeownership" (Board of Governors of the Federal Reserve System, January), www.federalreserve.gov/pubs/oss/oss2/papers/weight. revision.pdf.

41. For more information on sample design, questionnaire development, and interviewing protocols, refer to the Surveys of Consumers website, at www.sca.isr.umich.edu/main.php. 
ing technologies. Some of these additional questions were based on questions in the Survey of Consumer Finances to allow for comparison of responses to the two surveys.

Interviews were conducted by telephone, with telephone numbers drawn from a cluster sample of residential numbers. The sample was chosen to be broadly representative of the four main regions of the country-Northeast, Midwest, South, and West-in proportion to their populations. Alaska and Hawaii were not included. For each telephone number drawn, an adult in the family (as previously defined) was randomly selected as the respondent. The surveys yielded data from 1,000 respondents in 1999 (October and November surveys combined), 1,002 respondents in 2003 (June and July surveys combined), and 1,002 respondents in 2006 (November and December surveys combined). The collected data were weighted to be representative of the population as a whole, thereby correcting for differences among families in the probability of their being selected as survey respondents. All survey data in the tables are based on weighted observations.

As with the Survey of Consumer Finances, the analysis was restricted to those households that reported having an account with a bank, thrift institution, or credit union. For the 1999 survey, this group constituted 89 percent of households; for the 2003 survey, 86 percent; and for the 2006 survey, 92 percent. 
B.1. Proportion of consumers who bank online and reasons for banking online, by demographic characteristic, selected years Percent

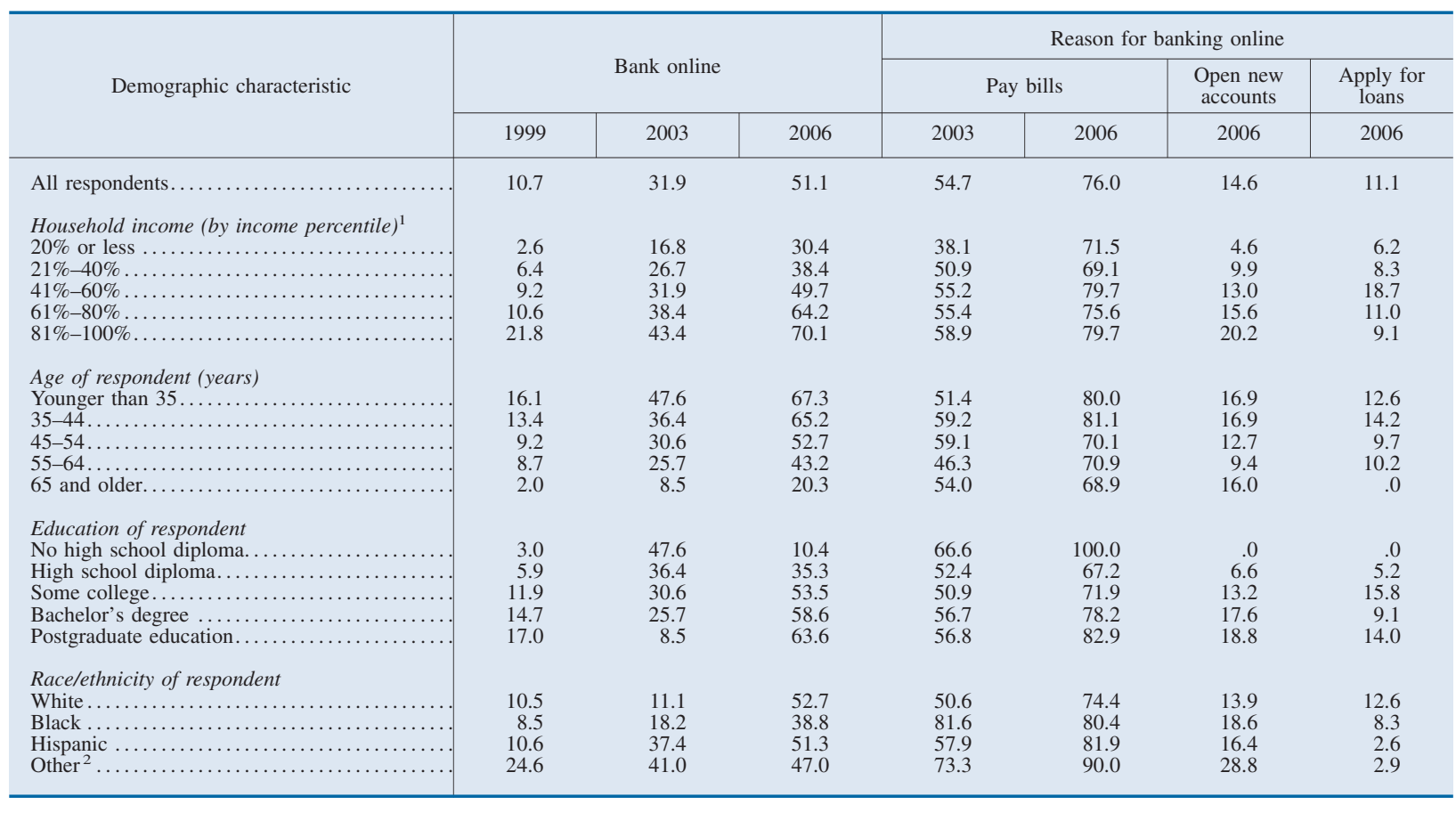

1. Income percentiles are based on the income of all responding households. 2. Includes Asian, Pacific Islander, and Native American. Thus, of respondents in the lowest 20 percent of the income distribution, Source: Michigan Surveys of Consumers.

2.6 percent banked online in 1999 and 30.4 percent banked online in 2006.

B.2. Proportion of consumers who would use contactless or wireless payments in the future, by demographic characteristic, 2006

Percent

\begin{tabular}{|c|c|c|c|c|c|c|c|c|c|c|c|c|c|}
\hline \multirow{3}{*}{ Demographic characteristic } & \multicolumn{7}{|c|}{ Contactless payments } & \multicolumn{6}{|c|}{ Wireless payments } \\
\hline & \multirow{2}{*}{$\begin{array}{l}\text { Have } \\
\text { used }\end{array}$} & \multicolumn{3}{|c|}{ All respondents } & \multicolumn{3}{|c|}{ Online bankers } & \multicolumn{3}{|c|}{ All respondents } & \multicolumn{3}{|c|}{ Online bankers } \\
\hline & & Yes & Maybe & No & Yes & Maybe & No & Likely & Even & Unlikely & Likely & Even & Unlikely \\
\hline All respondents. . & 19.4 & 37.8 & 14.7 & 47.5 & 51.6 & 13.8 & 34.6 & 16.3 & 7.2 & 76.5 & 24.0 & 7.7 & 68.2 \\
\hline 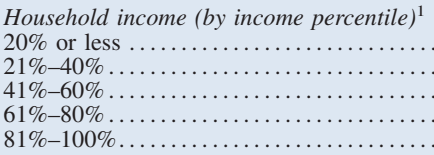 & $\begin{array}{r}2.6 \\
11.1 \\
14.8 \\
25.9 \\
39.7\end{array}$ & $\begin{array}{l}30.2 \\
27.6 \\
35.7 \\
46.1 \\
55.5\end{array}$ & $\begin{array}{l}12.5 \\
13.8 \\
16.3 \\
15.1 \\
13.3\end{array}$ & $\begin{array}{l}57.3 \\
58.7 \\
48.0 \\
38.8 \\
31.2\end{array}$ & $\begin{array}{l}59.7 \\
43.4 \\
42.5 \\
48.9 \\
63.1\end{array}$ & $\begin{array}{r}7.6 \\
10.4 \\
19.5 \\
14.9 \\
9.6\end{array}$ & $\begin{array}{l}32.8 \\
46.2 \\
38.0 \\
36.2 \\
27.3\end{array}$ & $\begin{array}{l}13.8 \\
16.8 \\
12.0 \\
16.8 \\
23.8\end{array}$ & $\begin{array}{r}6.8 \\
5.5 \\
5.2 \\
7.5 \\
10.5\end{array}$ & $\begin{array}{l}79.4 \\
77.7 \\
82.9 \\
75.7 \\
65.7\end{array}$ & $\begin{array}{l}18.6 \\
30.2 \\
19.9 \\
18.8 \\
28.5\end{array}$ & $\begin{array}{l}1.6 \\
8.3 \\
7.2 \\
8.0 \\
9.6\end{array}$ & $\begin{array}{l}79.8 \\
61.6 \\
73.0 \\
73.3 \\
62.0\end{array}$ \\
\hline $\begin{array}{l}\text { Age of respondent (years) } \\
\text { Younger than } 35 \ldots \ldots \ldots \ldots \\
35-44 \ldots \ldots \ldots \ldots \ldots \ldots \ldots \ldots \ldots \\
45-54 \ldots \ldots \ldots \ldots \ldots \ldots \ldots \ldots \\
55-64 \ldots \ldots \ldots \ldots \ldots \ldots \ldots \\
65 \text { and older. }\end{array}$ & $\begin{array}{l}22.7 \\
28.5 \\
20.3 \\
15.3 \\
10.0\end{array}$ & $\begin{array}{l}50.5 \\
44.6 \\
40.6 \\
37.3 \\
16.8\end{array}$ & $\begin{array}{r}9.7 \\
17.2 \\
15.2 \\
17.3 \\
14.5\end{array}$ & $\begin{array}{l}39.8 \\
38.2 \\
44.2 \\
45.5 \\
68.7\end{array}$ & $\begin{array}{l}56.5 \\
57.0 \\
44.4 \\
50.2 \\
37.0\end{array}$ & $\begin{array}{r}5.7 \\
14.1 \\
16.1 \\
20.3 \\
24.1\end{array}$ & $\begin{array}{l}37.8 \\
28.9 \\
39.5 \\
29.5 \\
38.9\end{array}$ & $\begin{array}{r}27.6 \\
24.0 \\
13.1 \\
10.6 \\
6.3\end{array}$ & $\begin{array}{r}10.4 \\
7.9 \\
9.3 \\
6.0 \\
2.5\end{array}$ & $\begin{array}{l}62.1 \\
68.1 \\
77.6 \\
83.4 \\
91.1\end{array}$ & $\begin{array}{r}32.4 \\
30.9 \\
18.9 \\
8.0 \\
10.9\end{array}$ & $\begin{array}{r}6.3 \\
7.4 \\
11.1 \\
8.0 \\
4.2\end{array}$ & $\begin{array}{l}61.4 \\
61.8 \\
70.1 \\
83.9 \\
84.9\end{array}$ \\
\hline $\begin{array}{l}\text { Education of respondent } \\
\text { No high school diploma.... } \\
\text { High school diploma....... } \\
\text { Some college............. } \\
\text { Bachelor's degree ......... } \\
\text { Postgraduate education.... }\end{array}$ & $\begin{array}{r}2.8 \\
10.4 \\
13.2 \\
28.0 \\
33.3\end{array}$ & $\begin{array}{r}8.2 \\
27.2 \\
35.5 \\
47.2 \\
53.2\end{array}$ & $\begin{array}{l}21.2 \\
10.1 \\
17.7 \\
15.6 \\
13.7\end{array}$ & $\begin{array}{l}70.7 \\
62.8 \\
46.9 \\
37.2 \\
33.1\end{array}$ & $\begin{array}{l}50.0 \\
43.3 \\
43.8 \\
54.2 \\
63.7\end{array}$ & $\begin{array}{r}.0 \\
9.2 \\
19.1 \\
14.2 \\
10.2\end{array}$ & $\begin{array}{l}50.0 \\
47.5 \\
37.2 \\
31.6 \\
26.1\end{array}$ & $\begin{array}{r}8.8 \\
18.3 \\
11.9 \\
18.3 \\
18.9\end{array}$ & $\begin{array}{r}5.6 \\
4.9 \\
6.0 \\
7.2 \\
13.2\end{array}$ & $\begin{array}{l}85.7 \\
76.8 \\
82.1 \\
74.5 \\
67.9\end{array}$ & $\begin{array}{r}.0 \\
35.4 \\
15.4 \\
24.8 \\
25.4\end{array}$ & $\begin{array}{r}.0 \\
1.2 \\
5.5 \\
8.5 \\
14.2\end{array}$ & $\begin{array}{r}100.0 \\
63.5 \\
79.1 \\
66.7 \\
60.4\end{array}$ \\
\hline $\begin{array}{l}\text { Racelethnicity of respondent } \\
\text { White } \ldots \ldots \ldots \ldots \\
\text { Black } \ldots \ldots \ldots \ldots \\
\text { Hispanic } \ldots \ldots \ldots \ldots \ldots \ldots \ldots \\
\text { Other }^{2} \ldots \ldots \ldots \ldots \ldots\end{array}$ & $\begin{array}{l}19.7 \\
12.3 \\
19.5 \\
29.4\end{array}$ & $\begin{array}{l}38.1 \\
37.8 \\
39.4 \\
32.4\end{array}$ & $\begin{array}{r}14.5 \\
7.6 \\
27.7 \\
12.6\end{array}$ & $\begin{array}{l}47.3 \\
54.7 \\
32.9 \\
55.0\end{array}$ & $\begin{array}{r}52.4 \\
43.2 \\
68.0 \\
5.4\end{array}$ & $\begin{array}{r}13.6 \\
9.9 \\
17.5 \\
16.2\end{array}$ & $\begin{array}{l}34.0 \\
46.9 \\
14.4 \\
78.4\end{array}$ & $\begin{array}{l}14.5 \\
23.5 \\
23.5 \\
24.1\end{array}$ & $\begin{array}{r}7.1 \\
4.6 \\
7.2 \\
14.5\end{array}$ & $\begin{array}{l}78.4 \\
72.0 \\
69.3 \\
61.4\end{array}$ & $\begin{array}{l}22.9 \\
22.7 \\
28.3 \\
37.5\end{array}$ & $\begin{array}{r}7.4 \\
11.3 \\
4.4 \\
17.2\end{array}$ & $\begin{array}{l}69.8 \\
66.0 \\
67.3 \\
45.3\end{array}$ \\
\hline
\end{tabular}

Note: Components may not sum to 100 percent because of rounding.

1. Income percentiles are based on the income of all responding households.

Thus, of respondents in the lowest 20 percent of the income distribution,

2.6 percent had used a contactless payment device in 2006 and 30.2 percent said they would use contactless payments in the future.
2. Includes Asian, Pacific Islander, and Native American.

SourCE: Michigan Surveys of Consumers. 